\title{
3. Distinguishing Hierarchy and Precedence: Comparing status distinctions in South Asia and the Austronesian world, with special reference to South Sulawesi
}

\section{Greg Acciaioli}

\section{Introduction}

The importance of differential status in the societies of archipelagic Southeast Asia and the greater Austronesian world is conspicuous; the proper terms for analysis of this social phenomenon remain, however, problematic. In this paper I wish to explore some of the ways in which questions of differential status have been addressed. Specifically, I want to examine the notion of hierarchy, as it has been elaborated from the work of Louis Dumont (1980). In this treatment I suggest that his use of hierarchy in the analysis of South Asian caste has been somewhat misconstrued (largely due to misleading comments by Dumont himself) and propose a different generalized understanding of hierarchy based on the analysis of caste. This reframed understanding of hierarchy may then be contrasted with the notion of precedence that James J. Fox (1994) and several of his students have argued (convincingly) is appropriate to the study of many Austronesian societies. By suggesting more explicit notions of hierarchy and precedence, I hope to disentangle some of the confusing ways in which differential status has been discussed for societies of this region and suggest some more restricted ways in which these concepts might be employed more powerfully and less ambiguously. I use the example of Bugis and Makasar domains of South Sulawesi as a context in which to deploy these understandings, arguing that their peculiar intermeshing of hierarchy and precedence distinguishes them from societies also informed by precedence elsewhere in the archipelago, especially in eastern Indonesia.

\section{The Logic of Hierarcy: Value and Exclusion in Caste}

In his overview of stratification in Asia, Evans (1993:212) uses the term 'hierarchy' as a generic, indeed self-evident, term for the cultural ordering principles underlying stratified social systems. Specifically, in regard to South Asian caste, he equates hierarchy with the principles by which culturally discrete groups are ordered with respect to one another. When used in this general sense, the term hierarchy may be used for most any stratified society. However, those 
analysts more orientated to interpreting the particular logics, the underlying structural principles, of local cultural systems have tended to adopt Dumont's (1980) more specific characterization of hierarchy in his culturalist analysis of the South Asian caste system.

Other scholars' invocations of Dumontian notions of hierarchy as the basis of caste and other analogous examples of status ranking have demonstrated a curious tendency. Rather than examining the way in which Dumont has utilized the notion of hierarchy in his substantive analysis of caste, they (for example, Fox 1994; Allen 1985) have derived much of their basic sense of the Dumontian characterization of hierarchy from the 'Postface: Toward a Theory of Hierarchy', which Dumont (1980:237-240) added to the revised edition of Homo hierarchicus (first edition published in French in 1966). Dumont has explicitly acknowledged that the underlying conceptualization of this postface was based upon his study of a section of Apthorpe's unpublished D Phil thesis at Oxford 'subsequent' (Dumont 1980:239) to writing the original manuscript of Homo hierarchicus. In the version put forth in the 'Postface' he posits the basic principle of hierarchy as the encompassing/encompassed relation or, somewhat differently stated, the encompassing of the contrary in asymmetric opposition (Dumont 1980:241). This relationship is demonstrated by a box contained within a larger box as opposed to the simple relation of complementarity in which two adjacent boxes make up a unity (Figure 1). As Dumont puts it:

I think the clearest formulation is gained by separating and combining two levels. At the superior level there is unity; at the inferior level there is distinction, there is, as in the first case, complementariness or contradiction. Hierarchy consists in the combination of these two propositions concerning different levels. In hierarchy thus defined, complementariness or contradiction is contained in a unity of a superior order (1980:242).

As Fox (1994:90) has noted, this relationship corresponds with what others, most notably Jakobson and Greenberg ${ }^{1}$ in linguistics, have identified as marking or markedness theory. In linguistic terms, this means that one member of an opposition (usually binary) may also stand for the opposition as a whole. For example, until the emergence of gender-neutral English, the personal pronoun 'he' could stand for agents of either gender at one level of contrast, though at a lower level of contrast 'he' was explicitly contrasted to 'she' as male to female. Fox (1994:91) has ingeniously exemplified how a term like 'man' may operate recursively as an unmarked form, encompassing an opposition of which it is itself one term, on a number of levels. ${ }^{2}$

However, I suggest that despite Dumont himself overtly labelling this postface as an extension of his own approach to caste in South Asia into a general theory of hierarchy, this conceptualization in terms of marking theory really does not capture the thrust of his own analysis of hierarchy in caste in the preceding 
chapters of his work Homo hierarchicus. In short, his afterword is more of an afterthought than a generalization. To support this characterization, I wish to traverse some of the major characteristics of Dumont's analysis of caste, a task to which I cannot fully do justice in the short compass allotted here. Hopefully, however, this traversal will highlight some aspects of caste that can enable a clearer contrast later with the notion of precedence. Dumont himself tended to use the term 'precedence' almost as a synonym of hierarchy: 'Nowadays hierarchy, or rather the existence of an order of precedence, a status ranking, usually compels recognition ...' (Dumont 1980:75). But I hope to show from the terms of Dumont's own analysis that some fruitful distinctions can be made, although such a revised conceptualization requires going beyond some of Dumont's own terms. Later, I will illustrate the applicability and articulation of these distinctions with some examples from the operation of status among the Bugis and Makasar of South Sulawesi.

\section{Figure 1. Homo hierarchicus (after Dumont 1980:242)}
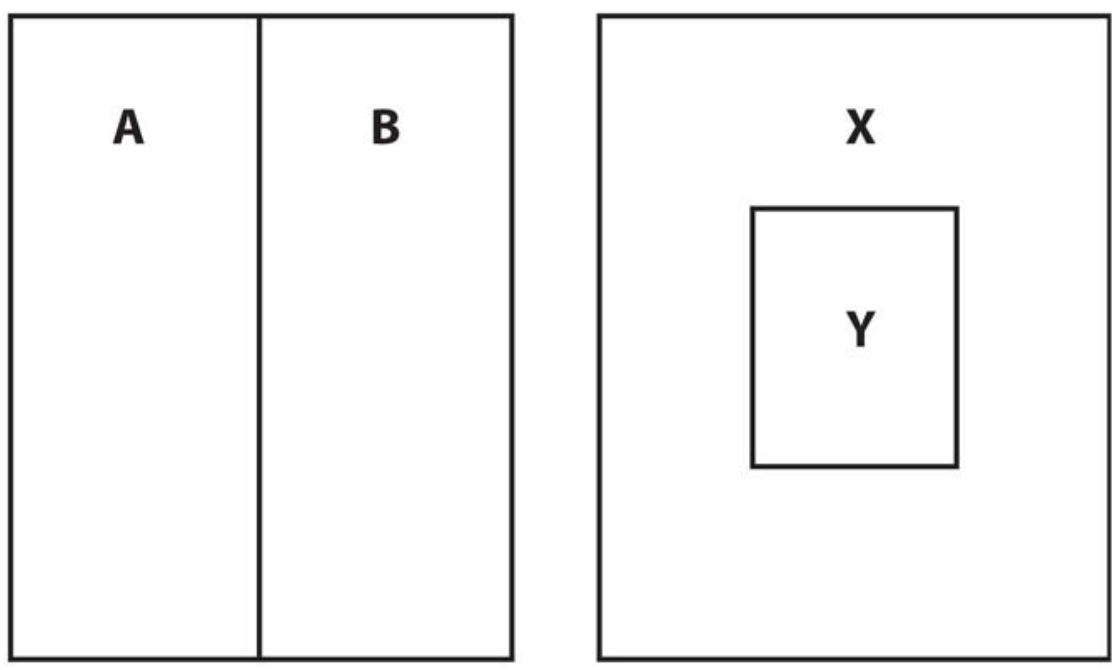

\section{The Logic of Hierarchy}

In many ways the fundamental structural logic of the caste system may be expressed as the recursive application of the asymmetric opposition of the pure and the impure. Dumont makes this basic point in chapter II of Homo hierarchicus (1980:43) after having devoted his first chapter to an overview of some past approaches to caste in the history of ideas. This opposition pure/impure is properly characterized as asymmetric, as one term of the opposition is valued more highly than the other. However, an asymmetric opposition is not necessarily a marked opposition; that is, it may not be the case that one of the terms serves to label the whole opposition, as well as contrasting with the other term (although 
all marked oppositions are, by definition, also asymmetric). In the case of caste, I would argue that this opposition is indeed not one of markedness, for in the recursive application of this opposition to form a hierarchy of castes, there is no identity of nodes across the levels of the hierarchy.

This property is most evident in the generation of the basic categorial division of South Asian society into varna, the 'colours' or 'estates' serving as the all-encompassing framework by which to render distinct caste hierarchies of various regions comparable. This division operates by the recursive application of the pure/impure (or, if one wishes to capture the relative nature of the contrast, purer/less pure) opposition, the subject of Dumont's third chapter. ${ }^{3}$ As I discuss these levels, the first term I will mention occupies the position of [+pure term], while the second that of the [-pure term]. As Figure 2 shows, the first opposition is that of the varna system as a whole against the category of those who are outside the varna system, i.e. the Untouchables. Within the varna system itself, the operation of the pure/impure opposition at the next level divides the triwangsa ('twice-born') from the Shudras, ${ }^{4}$ who are only once-born. Within the twice-born, the subsequent operation of the pure/impure opposition divides off those who can exercise dominion from those who cannot, that is, the Vaishyas. Among those who can exercise dominion, the Brahmans are finally distinguished from the Kshatriyas as those who are allowed to perform sacrifice due to their greater purity. Thus, the recursive operation of the asymmetric pure/impure opposition has generated the four varna of South Asian society, along with the structural residue of those too impure to be within the varna system itself.

It may be argued that, in one sense, the recursive operation of the opposition may be seen as one in which the pure always encompasses the impure, since it is successive degrees of purity that are distinguished. Each succeeding node going down the layers could be labelled [+pure]. But it is important to note that one could not label each node as Brahman in ever more restricted senses until one arrives at the most restricted sense of Brahman in the final level of contrast. A Kshatriya is not a type of Brahman at the next higher level (nor vice versa), in the way that a woman is a type of man, when man is used as an unmarked category to encompass the man/woman opposition. According to Dumezil, whom Dumont explicitly cites as the inspiration for his own analysis of caste as a recursive succession of dichotomies (Dumont 1980:67-68), the Brahmans and Kshatriyas together compose the 'two forces' (ubhe virye), while the 'two forces' along with the Vaishyas compose the 'twice-born', and the 'twice-born' plus the Shudras compose the varna as whole. So to label the levels of the system is simply to work up the levels (from greater to lesser purity) which I worked down (from lesser to greater purity) in generating the system. The labels at each level once more illustrate that no intermediate node is the same as one of the two nodes into which it is divided by the subsequent application of the pure/impure opposition. The figure thus resembles more closely a key (Fowler 
1977:225-226) or tree (Tyler 1969:10-11) rather than a taxonomy; the nodes label underlying semantic features rather than categories, although in this case, unlike most keys or trees, it is the same feature operating at each node, thus exemplifying recursiveness.

\section{Figure 2. Hierarchy in Hindu varna system}

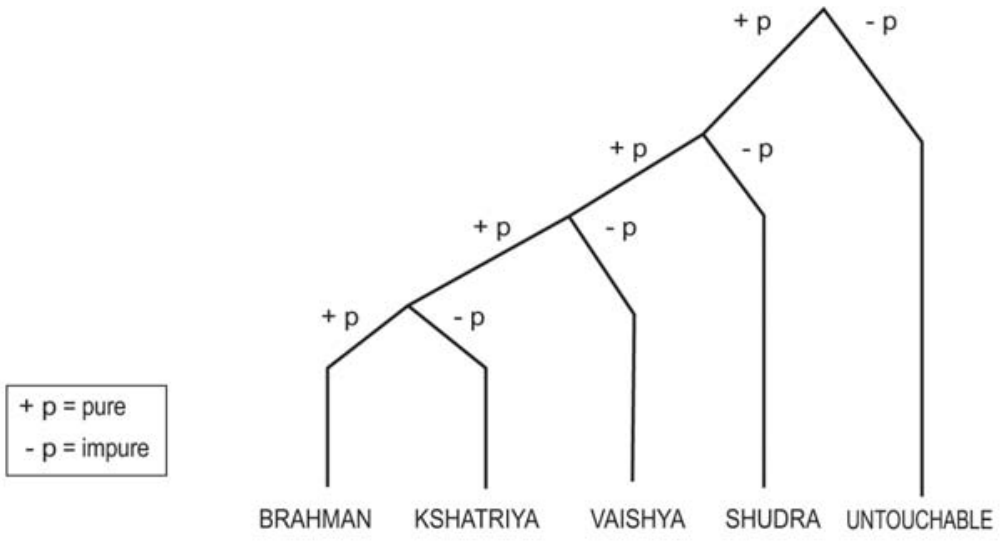

+ varna / - varna

\begin{tabular}{|c|c|c|c|c|c|}
\hline \multicolumn{4}{|l|}{ + twice-born / - twice-born } & & \\
\hline \multicolumn{3}{|l|}{+ dominion / - dominion } & & & \\
\hline \multicolumn{2}{|c|}{ + sacrifice perf. / - sacrifice perf. } & & & & \\
\hline & BRAHMAN & KSHATRIYA & VAISHYA & SHUDRA & UNTOUCHABLE \\
\hline
\end{tabular}

The division of South Asian society into the actual castes (jati) of specific regions can be conceptualized in much the same way. As shown by Figure 3, it is once again the successive operation of the pure/impure distinction that separates clumps of castes from each other. However, moving from the varna model of Indian society to the level of actual castes complicates the homogeneity of the analysis. As Dumont himself notes:

The caste, unified from the outside, is divided within. More generally, a particular caste is a complex group, a successive inclusion of groups of diverse orders or levels, in which different functions (profession, endogamy, etc.) are attached to different levels (1980:34).

Basically, the division into castes in a region may be analysed structurally by regarding the asymmetric pure/impure relationship as a meta-opposition, which is realized in specific oppositions as a number of different criteria. For example, with reference to Figure 3, representing a hypothetical case, the criterion of members eating meat may divide one set of groups $(A, B, C, D)$, those who do not eat meat, as relatively pure, as opposed to the relatively impure groups who do 
eat meat $(\mathrm{E}, \mathrm{F}, \mathrm{G}, \mathrm{H})$. However, another criterion will divide the whole set of groups into two different subsets. Groups $\mathrm{A}, \mathrm{B}$, and $\mathrm{C}$ are distinguished from all those below (D, E, F, G, and H) by their refusal to accept food from meat-eaters, a characteristic that ranks them as relatively purer than those latter groups that do accept meat. Simply by using these two criteria, group D has been isolated as occupying a unique niche in the middle of the set, for it is the only group that does not eat meat, but will accept other kinds of food from members of meat-eating groups. This manner of using criteria differentially to isolate terms, which are thus defined by unique strings of components, the values of the intersecting criteria, thus corresponds to distinguishing terms according to a paradigm rather than a taxonomy or key (Fowler 1977:223-225; Tyler 1969:9-10). As Figure 3 shows, by successively applying a number of such oppositions that isolate subsets of groups at different points along the spectrum, with those on the left of the line of distinction always judged as purer than those on the right, eventually each of the groups is distinguished by a unique set of restrictions. For example, members of group A do not eat meat, do not accept other kinds of food from meat-eaters, do not allow widows of their group to remarry, do arrange infant marriage, do not eat beef (a redundant feature for this group, since its members do not eat any kind of meat), and do not tan leather. Members of group B observe all the same restrictions, except for arranging infant marriages for their children, thus being ranked as somewhat lower than group A's members in regard to purity due to nonobservance of that one criterion.

Although admittedly hypothetical in its specific clustering of oppositions, this example does, however, reveal how a large number of groups can be distinguished simply by the iterative application of the pure/impure meta-opposition with regard to a number of criteria. Some of these criteria are distinct, while others may be related by entailment and hence redundant for some groups. For example, for those who do not eat meat, the question of eating other specific types of meat, beef vs. nonbeef or domestic vs. wild, simply does not arise. But these latter distinctions are significant in determining the ranking of those castes whose members do eat meat. Examination of the structural logic of this case makes even clearer why the characterization of hierarchy as the encompassment of the contrary does not quite capture the dynamics of caste hierarchy. As the figure reveals, there is no single path of application of the pure/impure distinction, and the series of terminal nodes of the diagram, that is, the specific castes that are separated into distinct categories with a unique constellation of observances and prohibitions, does not contain any single category that can represent higher nodes or groupings of the castes at intermediate levels. 
Figure 3. Logic of inclusion/exclusion in Hindu caste hierarchy

C A S T E S

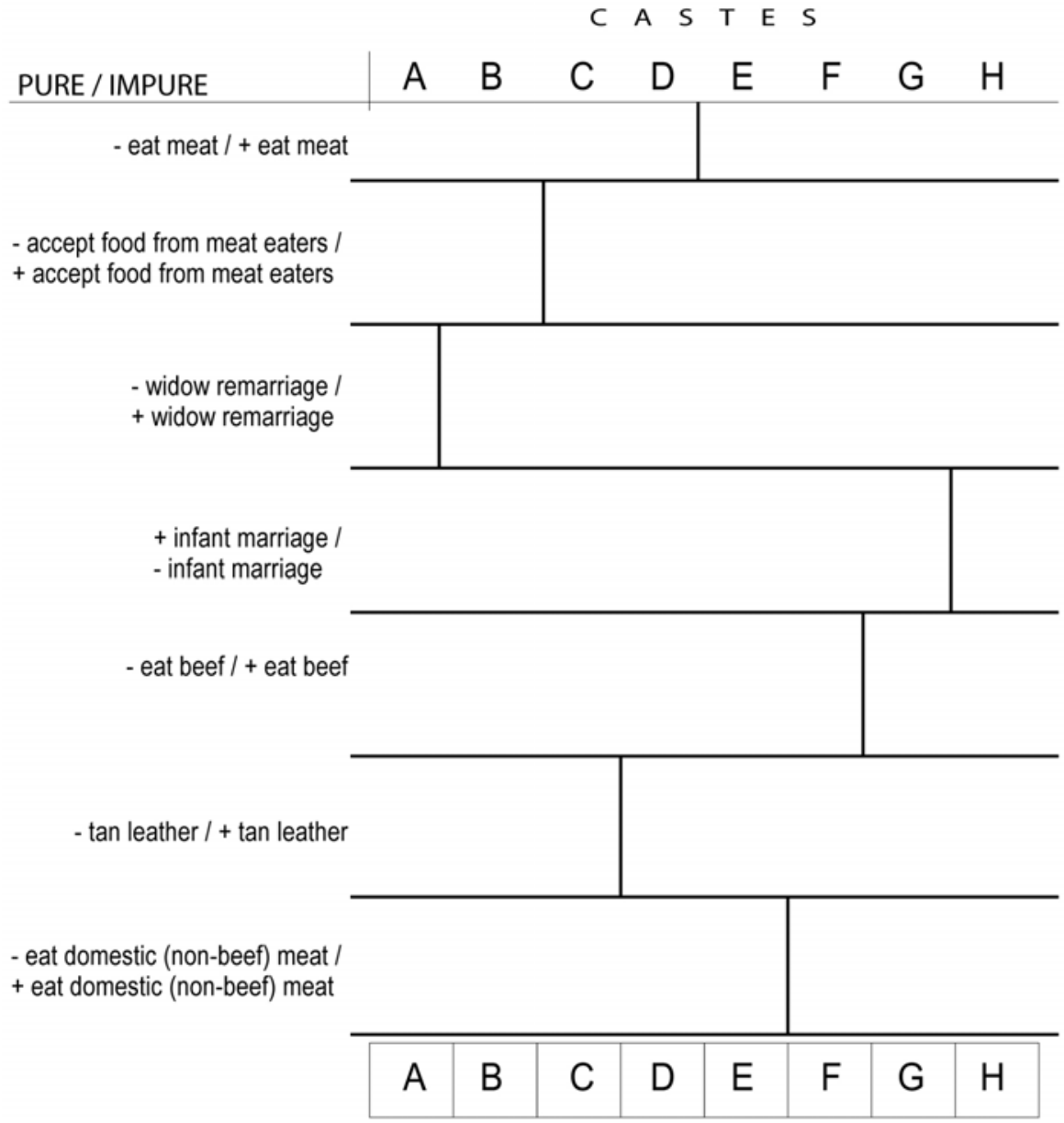

Two characteristics, however, do stand out as underlying this structural logic, and it is these, I argue, that distinguish hierarchy as a particular type of status ranking procedure. First is the issue of unitary value. In his postface Dumont himself emphasizes the importance of value, defined as the according of superior and inferior poles to the oppositional relation, to the construction of hierarchy (Dumont 1980:244). What strikes me is that it is not so much the attribution of value (that is, asymmetry) that is distinctive of hierarchy, but the constitution by unitary value. That is, the hierarchical system can be generated by the recursive application of a single differentiation in value, in this case that of pure vs. impure. Fox $(1994: 95,106)$ too has noted that this single opposition is the 'basis of all hierarchy' for Dumont. Although the criterion of separation may be different for the specific opposition applied at each level, the terms defined by each criterion may be judged in terms of the value defined by the 
meta-opposition 'pure/impure'. Indeed, that is the rationale of all the specific oppositions.

Secondly, the system does not operate as a mechanism for successive encompassment, which is by definition a type of inclusion. Rather, the point of the whole system is successive or graduated exclusion. Those who can be characterized as occupying the pure pole on the greatest number of criteria are classed as at the top. As noted by Pocock (1957), in the very paper which Apthorpe cited as inspiring his own elaboration of hierarchy, the end which those at the top attempt to attain is the exclusion of those aspiring to their own status. This goal local actors strive to achieve by various strategies of endogamy (Pocock 1957:28), which may lead to the construction of endogamous marriage circles that may congeal, in time, into subcastes or even castes (Pocock 1957:22). Of course, this tendency is also countered by those from lower groups who seek to be identified with members of the higher groups by a countervailing process of inclusion which is realized in various hypergamic strategies. But the overall thrust of the recursive application of the single valued opposition is to emphasise the dynamics of exclusion as an end to the system. Indeed, our understanding of caste as a unique social formation depends heavily on the exclusive character of its strata, with caste endogamy seen as more definitive of the cultural system than hypergamy despite the empirical incidence of the latter.

\section{The Logic of Precedence}

I have emphasized these two characteristics of hierarchy - unitary value and exclusion as an aim - precisely in order to distinguish it from the notion of precedence. In one of his most explicit theoretical treatments of this latter concept, Fox (1994) notes that there is no absolute distinction between precedence and hierarchy, although each exhibits different potentials given the development of each in association with analyses of a particular ethnographic context, that of South Asia in the case of hierarchy and that of the Austronesian world, particularly eastern Indonesia, in the case of precedence. Both systems of status discrimination are based on a notion of opposition, and indeed of asymmetric, but also complementary opposition. Fox (1994:87) has 'argued that an "hierarchical" use of dual categories involves the conjunction of two analytic features: categorical asymmetry and recursive complementarity'. As his own examples later in the same article attest, the same two features characterize the operation of systems of precedence as well.

What Fox does emphasize as distinctive of precedence is the complex operation of a number of valent oppositions, rather than simply the continued operation of one privileged (meta-)opposition. This multiplicity or diversity of relevant oppositions facilitates the possiblity of categorical reversals of valency of any categorical asymmetry. Precedence is thus subject to greater possibilities of social contention or contestation than hierarchy (Fox 1994:96-98). It is easier 
to move from a position as wife-taker to wife-giver in a system of asymmetric connubium organized by precedence than for a Shudra to leapfrog up to Kshatriya or even move simply to Vaishya status. Fox also emphasizes one other characteristic, which I feel is perhaps one of the most crucial hallmarks of prececedence: the necessity for 'an initial term or inception point' (Fox 1994:98 [my italics]). In the Austronesian case, Fox argues that this leads to a concern with 'origins' or 'sources', whether expressed spatially or temporally (and often in both modes). Precedence systems are generated on the basis of measuring social distance from some origin line or point. Most often, such systems in the Austronesian world are articulated by basic metaphors (Fox 1980b) that oppose branches to trunks or bases; the term that literally means 'trunk' or 'root' tends to be used metaphorically in these Austronesian languages to mean 'source' or 'origin'. Precedence is based on a movement from trunk to tip through a profusion of branches. Such a movement may be taken as a hallmark of precedence conceptually rather than just areally. And in certain respects the other characteristics that distinguish precedence systems may be seen to follow from this characteristic. Perhaps a couple of examples will best illustrate the operation of precedence systems.

\section{The Operation of Precedence in Eastern Indonesia}

Fox (1994:99-106) has already elegantly summarized the operation of precedence in the asymmetric connubium of the Timorese Atoin Pah Meto, the Javanese kinship terminology, and the dynastic politics of Termanu in Roti. Rather than recapitulating those examples, let me first simply highlight a major characteristic of the Timorese case before proceeding to two other examples. There the system of precedence works by the notion of degrees of proximity to the origin, an order of precedence enshrined in myth by temporal precedence and sustained in contemporary social relations by wife-giver/wife-taker relations in a fixed order. What is significant is how this system does not depend upon a system of exclusion and separation in terms of some common underlying notion, like degrees of purity. It is a system for assimilating or incorporating groups and building larger structures, precisely the function accorded to generalized exchange structures by Lévi-Strauss (1969). Although newer groups may be first incorporated at lower levels of the structure, the potential for reversing wife-giver/wife-taker relations provides the basis for leapfrogging in the system that allows the specific status order to be reconfigured, although the basic asymmetric opposition and warrant of the system — wife-givers are of higher status than wife-takers - remains stable.

The Ata Tana 'Ai of central Flores demonstrate how a different set of overt social manifestations - earlier social theory would have labelled the Ata Tani Ai as matrilineal as opposed to attributing patrilineality to the Atoin Pah Meto - may realize the same logic of precedence. For the Ata Tana 'Ai, the term oda 
signifies the succession or order of events, the sequencing that makes up history (Lewis 1988:81). Oda is also the term used to label orders of social precedence among the Ata Tana 'Ai. For example, there is the order of precedence among clans in a domain, which depends, as in the Atoni Pah Meto example, on the order in which ancestors of the clans first came to the domain in the origin myths. This order of precedence determines the ranking of responsibility for the rituals that are deemed necessary for the continuity of the domain, as overall responsibility for the most important rituals rests with the origin clan, and ultimately with the 'Source of the Domain, the center, source, trunk, and foundation of the domain' (Lewis 1988:76), a functionary whose epithets clearly resonate with the trunk-tip metaphors of precedence elsewhere among Austronesian societies.

But oda is also relevant within the clans to set up a system of precedence operating, as in the Atoin Pah Meto case, through the dynamics of marriage exchange. In every clan there is one descent line considered as the pu'an, the source or origin, whose members claim descent from the first ancestor of the clan to arrive in Tana 'Ai. The descendants of these source ancestors make up a house (what previous kinship theorists would have labelled a lineage) within the clan; other houses within the clan are conceptualized as following behind the source house. This 'following behind' depends on a system of marriage in which the bestowal of men outside the clan (see Figure 4) should be reciprocated in the next generation by the return of a woman to marry a member of the original husband-bestowing clan, a usage labelled 'returning the father's forelock' (Lewis 1988:205ff.). The descendants of the woman bestowed then become a segment or a house of the now expanded clan into which she has returned through (father's forelock) marriage. Thus, within the clan the order of precedence is determined by the succession of returning a woman, the father's forelock, back to the house from which a man had been received in marriage. Here is Lewis's explanation of this figure:

In the first instance, a man of house Al marries a woman of clan B. One of his daughters is returned to clan A by means of the transfer of father's forelock. The daughter enters her father's clan, marries her father's sister's son, and founds within clan A the house A2. In the next generation, another man of house Al marries a woman of clan $\mathrm{C}$, and a man of A2 marries a woman of clan D. Daughters of these men are subsequently returned to clan A, marry their fathers' sisters sons, and found houses A3 and A4, respectively. House A5 is founded in the sixth generation as the result of the marriage of a man of house A4 to a woman of clan E. The oda ranking, that is, the order of precedence of the houses, is established by the order in which their founding mothers enter the clan (1988:230). 
Figure 4. The organization of houses within the clan Ata Tana 'Ai (Lewis 1988:230)

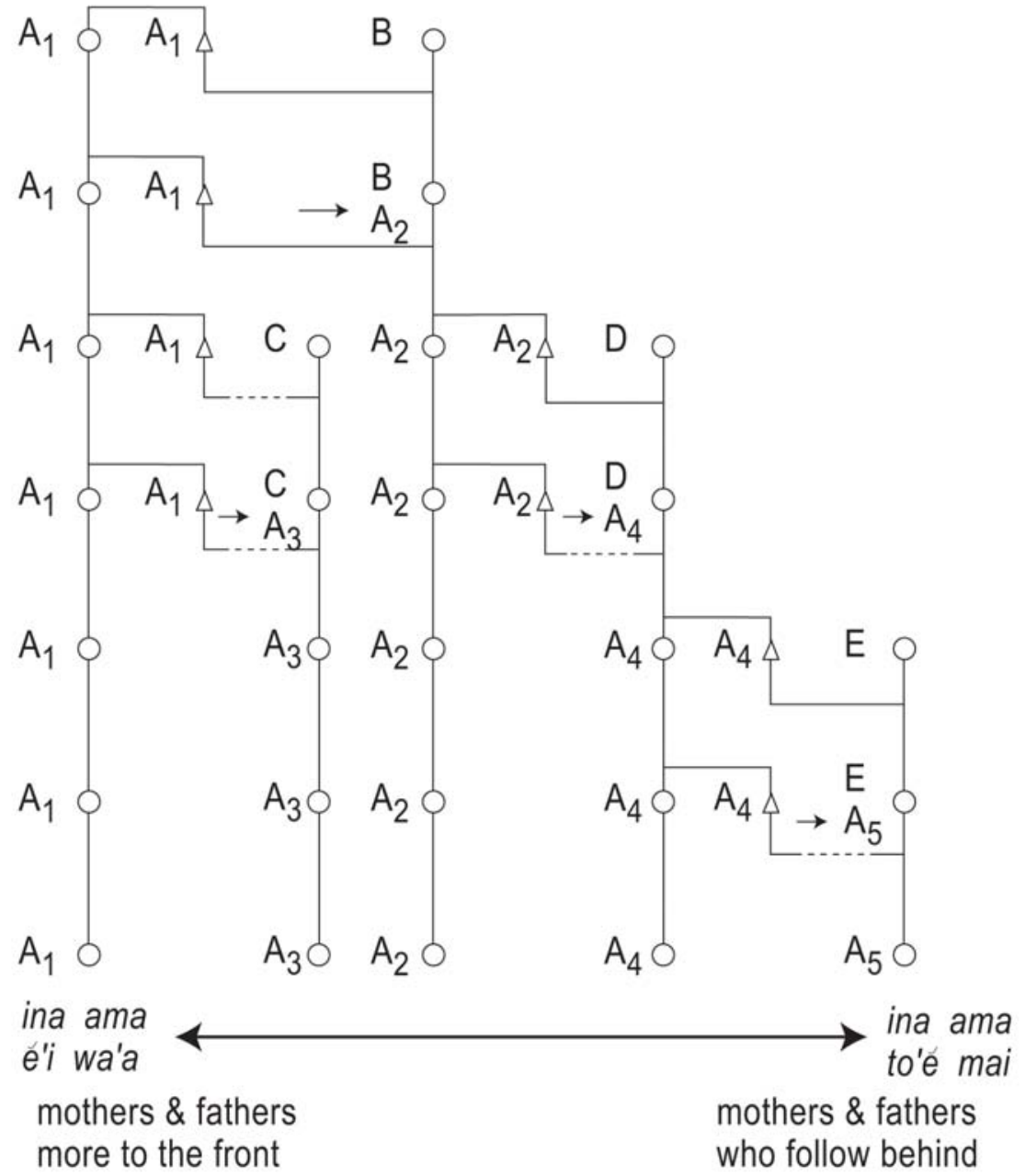

(after Lewis 1988: 230)

So, considered as houses within the clan, A1 is ranked higher than A2, while A2 is ranked higher than A3 and A4, which rank higher than A5, and so on in an order of precedence, according to the succession of marriage exchanges involving the father's forelock. The house to which one's own clan gives a woman as father's forelock is regarded as ahead in the order of precedence and labelled as ini ama e'i wa' 'mothers and fathers who are more to the front', while those to whom one bestows a man and subsequently receives a woman are ini ama to'e mai 'mother and fathers who follow behind'. The order of precedence is thus established by the order in which founding mothers enter the clan. This 
movement of other clans into the source clan as houses leads to a movement of women from the periphery to the centre of the clan, as men are spun off to more peripheral groups, resulting in greater consolidation of maternal descent groups in the centre: the central and older houses become relatively more powerful because they are wealthiest in term of the number of women. As Lewis describes the point of the whole system:

In Tana Wai Brama, daughters are wealth. The larger the number of women in a house, the greater is the productive capacity of the house and the larger the surplus from gardens that can be converted into ceremonial goods (to'o balik). A clan's reserves of ceremonial goods thus tend to be concentrated in the source house and those houses of the clan which are $e^{\prime} i w a^{\prime} a$, closer to the source, who wield corresponding power in the clan by virture of being able to decide how that wealth is used in securing (through father's forelock exchanges) women from other clans (1988:232; italics in original).

In contrast to the precedential ordering of social segments according to marriage exchanges among the Atoin Pah Meto and Ata Tana 'Ai, both largely interior swidden horticultural societies of eastern Indonesia, precedence also operates in other societies of different scale and social composition within the region by invoking other mechanisms. Status ranking in coastal Balinese rajahdoms or negara, to take one example of a society often regarded as more complex in regard to the multiplicity of groups and ways of assessing status, ${ }^{5}$ can also be analysed, at least in part, as organized by precedence. For example, as delineated by Geertz (1980), the ranking of royal houses depends upon a notion of distance from an origin line, as well as from an origin point. As Figure 5 reveals, the ruling line of Gelgel is seen as continually 'sinking' in status as it falls away through the generations from its origin in the god Batara, through the semi-divine mpu spirits, a term that like Tana 'Ai pu'an refers to source or origin. The royal line becomes that of the Dangiang Brahmana, who begets a line of Ksatriya rajahs, the Kresna kepakisan. Seven generations down the line, the ruler can only assume the lower title of Dewa Agung, while in the next generation, when the domain of Gelgel disintegrates and is replaced by Klungkung, the ruler suffers yet another drop in title status, as the process of 'sinking' continues off the diagram to the end of that dynasty. Fox (1995:224-225) has noted how this Balinese system of 'sinking status' is but one variant of the formal structure of 'apical demotion' that is characteristic of societies found on smaller islands in the Austronesian world whose elites, preoccupied with status, have developed this device to maintain their exclusivity ( $c f$. Fox on Termanu, this volume). 
Figure 5. Sinking status of royal lines in Bali (schematized from Geertz 1980)

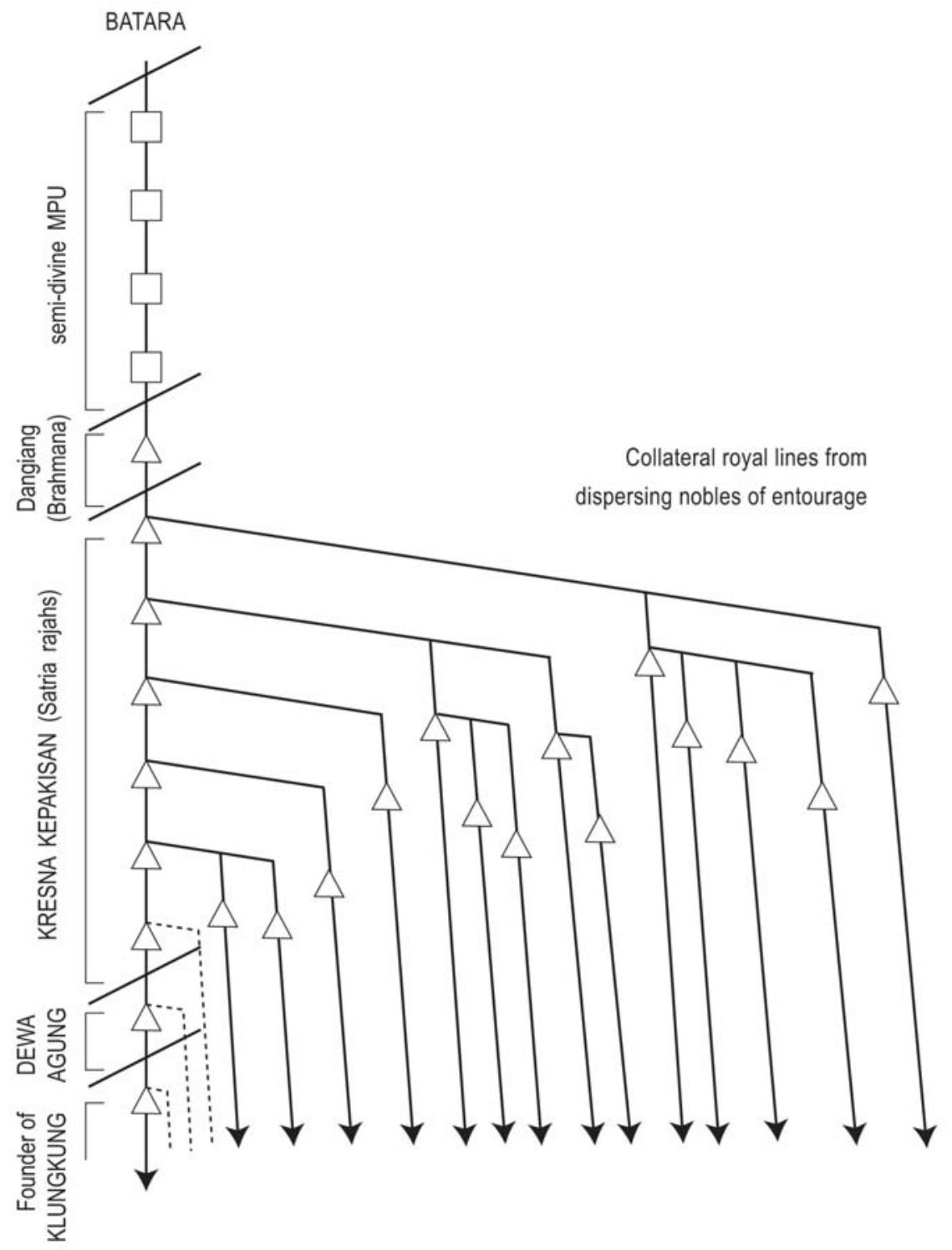

This line of the diagram demonstrates the operation of 'sinking status' (Geertz 1980:16ff.) with respect to the divine origin ancestor. But there is also a lateral movement, with noble members of the rajah's entourage breaking off to found their own domains away from the central palace. ${ }^{6}$ And these new royal lines are ranked too, with those that have diverged in earlier generations ranked as lower than those that break off closer to the reigning rajah of the origin line. Such an attribution is consistent with that of the origin line itself, since over the 
generations these diverging lines are conceptualized as moving further from the origin line by the principle of sinking status. Those local royal lines shown closer to the origin line in Figure 5, which means those that have broken away most recently, are higher in rank and those further away, those who have broken away earlier, some of which will have their own breakaway offshoots, are lower. Proximity to an origin point and to an origin line thus determines ranking in this system.

This same precedential logic based on a calculus of generational distance from an origin point and an origin line informs other levels of Balinese socio-political structure. The Balinese also have a patrilineal descent group organization, based on a unit called the dadia, which like the Tana 'Ai clan is composed of houses. Sinking status articulates the relations of houses within a dadia, as illustrated by Figure 6 . The earlier a line breaks away to form a house within a royal dadia, the lower its rank: noble house $\mathrm{A}$ is lower in status than noble house $\mathrm{B}$, which is lower than $\mathrm{C}$, which is lower than $\mathrm{D}$, and so on. The same principle of sinking status that orders royal lines among themselves also distinguishes the houses within a dadia. Status distinction in these aspects of Balinese sociopolitical structure depends upon notions of proximity to an origin line.

\section{Figure 6. Gentry descent: the principle of sinking status}

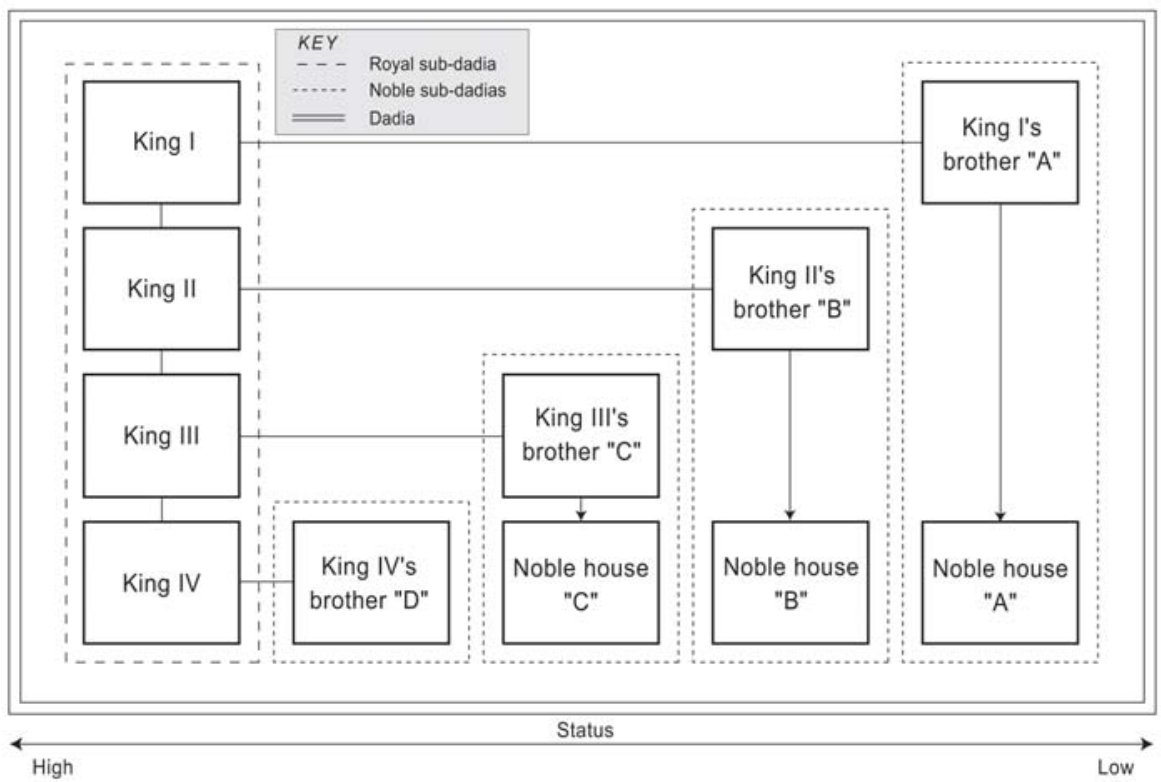


Interestingly, the Balinese of these negara reverse the value of the Ata Tana 'Ai order of precedence of houses of the clan. Among the Ata Tana 'Ai, those houses incorporated first through father's forelock marriage exchanges rank higher in the precedence system. In Bali those houses that diverge first from the main line within the dadia rank lower. Such a difference highlights two of the functions of precedential ordering. As in the case of Timorese marriages, precedence among the Ata Tana 'Ai operates to incorporate or include lines within a house, whereas with the Balinese dadia precedence operates to differentiate lines within the descent group. Such a difference is to be expected, as in the former cases precedence operates through an order of marriage exchanges, while in the latter it operates through an ordering of filiation and descent lines. Both functions, however, exemplify different operations of precedential logic. And in both cases there is still the option of manipulating the system through strategies involving categorical reversal. Precisely that potential is what differentiates the operation of these systems from hierarchical systems orientated primarily to exclusion rather than incorporation and differentiation.

\section{The Bugis and Makasar in South Sulawesi: Intermeshing Hierarchy and Precedence}

The analysis of the societies of the Bugis and Makasar peoples of South Sulawesi provides an interesting opportunity to examine the applicability of notions of hierarchy and precedence to a particularly problematic archipelagic Southeast Asian context. Errington (1989) has labelled the societies of South Sulawesi as more representative of hierarchical, centre-oriented Indic states than of eastern Indonesian systems organized by complementarity and exchange. Indeed, she classifies the polity of Luwu' in South Sulawesi and the other Bugis and Makasar realms of the southwestern peninsula as belonging to the 'Centrist Archipelago', encompassing (from the northern point proceeding clockwise) the Philippines, Halmahera, Buru, Sulawesi, Bali, Java, Kalimantan, and the Malay peninsula (Errington 1989, pt. III:207ff., map on p.208; reiterated in Errington 1990:39ff., map on p.xvii). Errington explicitly contrasts this Centrist Archipelago with eastern Indonesia in her earlier version (Errington 1989:209) and then with the 'Exchange Archipelago' in her later rendition (Errington 1990:39). ${ }^{7}$ Many of those working outside the Centrist Archipelago (for example, Forth 1992) have sharply criticized Errington's account for her failure to note the continuities that cut across her two archipelagoes, many of which are expressions of the precedence structures that occur as well in Sulawesi. Indeed, my own inclusion of the operation of precedence structures in Bali (see above) may be taken as yet another example of such continuities across her apparently contrasting units. Errington has also been taken to task by other reviewers for assuming that the polities of Sulawesi, Luwu' in particular, may be analysed as Indic states based 
on the mandala model of political power (for example, Babcock 1991; Caldwell 1991).

With these critiques I am in accord. One need only compare the way in which bamboo clumps are used to model the relations of social groups among the Bugis nobility of Luwu' and, to take but one example from eastern Indonesia, among the Ata Tana 'Ai, to realize the depth of continuities across the boundary Errington posits (Errington 1989:33, 215; Lewis 1988:75). ${ }^{8}$ However, when reading the accounts of ritual and social organization in eastern Indonesia, and even more forcefully when watching filmic accounts of the enactment of precedence in eastern Indonesian ritual, I cannot help but feel that there is a very different cast to the enactment of status difference in Bugis and Makasar rituals, most notably weddings (Millar 1983, 1989), in South Sulawesi (and coastal Central and Southeast Sulawesi as well) compared to their expression in eastern Indonesia. Errington may have somewhat misconstrued this difference by reducing the complexity of precedence, a term she does not herself use in a specific sense, in eastern Indonesian societies to the modelling of the relations of constituents upon elder/younger oppositions, both 'older brother'/'younger brother' $\left.{ }^{\text {sic }}\right]^{9}$ and older generation/younger generation (Errington 1989:206ff.) Her assertion that 'in the more hierarchical societies of island Southeast Asia, the generational layers are overlaid, but not displaced, by institutionalized structures of inheritable prestige' (Errington 1989:206) also leads to some further misconstruals, such as her subsequent assertion that it is (primarily) in these latter societies of the Centrist Archipelago that terms of respect tend to implicate ancestors or the 'source' (Errington 1989:206). However, Errington's phrasing of differences does lead one to posit a possible divergence in the way that precedence and hierarchy are intertwined in these societies. In the paragraphs that follow I hope to explore this difference by arguing for a different elaboration of hierarchy among these peoples of South Sulawesi, while noting the continued operation of precedence structures in arenas of status recognition and assertion.

Such an approach is not really novel. Accounts of Bugis and Makasar society have tended to emphasize the interplay of various features of status discrimination. On the one hand, the society has been described as articulated by a pervasive sense of hierarchy (for example, Pelras 1971, 1996:110). Nobles have the warrant to rule by virtue of prerogatives derived from their inherent qualities, whether conceptualized as the greater whiteness of their blood (Matthes 1875:4) or their greater concentration of potency (Errington 1983a). Commoners and slaves in this view 'naturally' carry out the commands of their betters with all due deference in recognition of their leaders' greater worth. Contrasting with this 'highly formalised class structure' ${ }^{10}$ (Chabot 1967:191), which pervasively influences the conduct of everyday life, is a complementary emphasis upon enterprise, the individualistic achievement of status through success in economic endeavours, political office, or educational achievement. On the one hand, a 
person's position is seemingly set by birth, an inherent status fixed unalterably by the positions of one's father and mother in the rank system. On the other hand, status is also the outcome of how well one competes in the arena of social life, the fortune that one creates for oneself and one's family through work (jama $[\mathrm{B}]^{11}$ ) (Acciaioli 2004). The system of ranks is at once inalterably fixed by custom (ade' $[\mathrm{B}]$ or adat [I]) and yet also fluid, for individuals can gain social recognition for a different ranking for themselves and for their families by manifest success in economic endeavours, masterful negotiation in political affairs, and scholarly accomplishments in education. Social hierarchy and economic enterprise, pervasive rank and competitive mobility, traditionalism and opportunism such oppositions have been put forth as constituting the distinctive dynamic of Bugis and Makasar society. What I hope to do is to reformulate some of these contradictions more elaborately by invoking more specified senses of hierarchy and precedence.

However contradictory these poles might appear, they are united in their orientation to certain cultural foci of the Bugis and Makasar. The assertion of status, both its maintenance and its achievement, is a primary concern, perhaps even an obsession in local culture. In her study of weddings in the Bugis domain of Soppéng, Millar has labelled this absorption a preoccupation with 'social location', of negotiating for ever higher positions (and making sure that one falls no lower) in variously defined status continua:

Social relations among the Bugis are fluid, equivocal, and competitive, yet strongly hierarchical. Within this society individuals simultaneously compete for higher achieved status, on the one hand, and jealously guard their privileges based upon ascriptive status on the other. Consequently, for the Bugis, the question of the social location of individuals is a matter of continuous tension; it is always important yet seldom certain (Millar 1989:1).

Rephrased in Bugis terms, it is a concern for defining one's place in relation to all others in the society, as Errington (1983b:197, 200ff.) has rightly noted.

The Bugis term onro, which is most often glossed as 'place', is marked by both geographical and social connotations. The definition in Said's dictionary of spoken Bugis stresses both physical location (tempat [I]) and social status or rank (derajat [I], literally 'degree', and pangkat [I], social position). Matthes's dictionary, highlighting more the literary form of Bugis used in lontara' manuscripts in Boné and elsewhere, begins its entry for onro (Matthes 1874:836) with a number of derived verbal forms that emphasize keeping one's whereabouts constant or a general physical stasis. For example, monroi daranna [B], literally 'her blood remains', signifies that a woman is not menstruating, thus implying that she is pregnant. However, the signification of the term relating to social status also emerges in such forms as to mangonrong, a debt slave. Thus, like the 
term empo used by the neighbouring Makasar people (Cense with Abdoerahim 1979:204), Bugis onro locates objects and individuals in a space that is both physical and social.

Such dual significance - one not unfamiliar to us in our own usages such as 'knowing one's place' - accords well with the functioning of Bugis society, especially the organization of social occasions. Social status is negotiated and validated precisely in such contexts as the organization of seating arrangements at a wedding feast or other ceremony. As Millar (1989) has shown, in such settings, physical place indexes relative rank. Ladies of higher rank sit on the upper platform at the front of the kitchen partaking of cakes, as lower status 'co-workers' toil at the pots beneath them. Hosts agonize over where to seat their guests, endeavouring always to reserve the front-row seats for the guests of highest rank. Traditionally, in the Bugis-Makasar area nobody could ever be seated on a level with the ruler. Physical placement thus signifies social location.

The rank that is signified by such placements is in theory articulated in the Bugis system of wari', the structure of status levels given as one of the five foundations of Bugis-Makasar society in the latoa and other lontara' manuscripts. ${ }^{12}$ According to Matthes (1874:641), the term wari' is related to the Makasar and Bugis term barrisi, meaning line or stroke, row or series (streep [D] rij [D]). The term is thus cognate with baris [I], which is the Indonesian gloss Said (1977:221) gives for the term wari' in his dictionary. Said also provides the gloss tuturkan [I], 'to relate, narrate, tell about'. Wari' thus has the sense of prescribing an unfolding narrative in a proper series. This indigenous theory posits a rigid system of status levels or ranks elaborating upon the three basic levels found throughout Sulawesi and elsewhere in the archipelago (not just the Centrist Archipelago!). A basic trichotomy of nobles, commoners and slaves provides the fundamental structure upon which is built a refined latticework of 'intermediate ranks' (tusschenstanden [D], as they are called in older Dutch works).

What I want to argue is that the wari' system of assessing rank operates as both a system of hierarchy and one of precedence. Its characterization in terms of the former construct derives from its recursive usage of a single idiom of differentiation — the possession or absence of white blood — and from its tendency to emphasize exclusion rather than incorporation or differentiation for the reproduction of the privileged centre of the system, or, to use Errington's problematic phrase, as 'a vast device, backed by (unstable) force for restricting access to potency' (Errington 1989:10). ${ }^{13}$ However, as the account below reveals, the system also has its foundations in a myth of origin, and in many ways the logic of differential nobility is based on increasing divergence from an origin point of deities of pure white blood, a movement that is reminiscent of the 'sinking status' of the Balinese. However, these deities are not regarded as the 
progenitors of humankind as a whole, but only of the nobility, regarded as a late emergent upon the social scene, rather than an origin that establishes a logic of precedence for the society as a whole. ${ }^{14}$

The wari' system operates to generate intermediate ranks between nobles and slaves as a result of intermarriages of white-blooded nobles with red-blooded commoners and slaves. Although various domains differ in the names accorded these lower nobles and the number of intermediate ranks recognized, the basic logic of their genesis is constant. A fundamental dichotomy is posited between nobles on the one hand and commoners and slaves on the other. Pure nobles, those theoretically most eligible for succession to the rulership of a domain, constitute a different order of being. Unlike mere mortals, they are the descendants of the tomanurung (Matthes 1875; Friedericy 1933; Pelras 1996:32), heavenly beings who descended to the land in order to establish order on a chaotic social landscape. ${ }^{15}$ Their pure descendants are entrusted with the task of continuing this order on earth; hence to them is reserved the theoretical right to rule. However, many of these descendants have intermarried with commoners and slaves. Their descendants are of less noble rank, a condition given symbolic expression as the dilution of their otherworldly 'white blood' with the red blood of mere worldlings. ${ }^{16}$ The idiom of white blood thus serves as a counter that exactly places all individuals on a scale of nobility in a manner theoretically determined only by marriage and descent. The marriage of a pure noble with a commoner or slave ${ }^{17}$ produces an intermediate rank of descendants with diluted white blood. Subsequent marriage of pure nobles with members of this intermediate rank produces yet another intercalated rank for descendants. These descendants are higher in rank than the progeny of nobles intermarried with pure commoners, but still of inferior or diluted status compared to the offspring of spouses who are both of pure heavenly (that is, white-blooded) descent. The members of this intercalated rank may then marry with pure nobles to produce yet another intermediate level for their descendants. This process may continue across the generations until eventually the rank of descendants produced is considered a scarcely distinguishable subcategory of the purest nobility. In the opposite direction, descendants of the intercalated noble ranks can marry downward with commoners or slaves to produce more intermediate levels of descendants that move toward the commoner end of the spectrum of rank. Eventually, the offspring of a marriage between a member of a sufficiently low intermediate rank and a spouse of the commoner level are considered as nonnoble, though perhaps commoners of a slightly elevated status (that is, tau décéng, literally 'the good people'), those who can claim a measure of aristocratic descent, but whose blood is sufficiently diluted so that they cannot exactly trace the original connections to noble forebears. 
The process of intercalating ranks, which moves both in the direction of the purest nobility and toward simple commoner status, can logically proceed without limit. Figure 7 presents a simplified, generalized model of this theory of intermediate rank generation, omitting a variety of possible marriages among the members of the intermediate ranks themselves. In fact, the number of recognized and labelled intermediate ranks determined by such marriages among members of different ranks constitutes one of the primary contrasts between the status systems of different domains in South Sulawesi. Figure 8 illustrates how the rank system of Wajo' as reported by van Rhijn and presented in Friedericy (1933:458-459) resembles to a great degree the logical model of Figure 7. ${ }^{18}$ However, the divergence of representations, as formalized from the same source (Friedericy 1933), of the rank systems of Mandar (Figure 9) and Goa (Figure 10), the latter the most powerful domain of the Makasar, also suggests that other factors militate against the potential for infinite gradation of ranks. As these diagrams illustrate, not only the number of intercalated ranks and the types of marriages that are asserted to generate them, but also the boundaries at which the major categories are delimited vary across domains. Whereas in Mandar and Goa only subdivisions of the nobility are created by these means, in Wajo' distinct status levels that are intermediate between pure nobility and commoners are generated. By such means the entire system is open to more variant interpretations, as the exact boundaries where nobility has become so diluted as no longer to warrant the title are rendered more obscure. As divisions multiply in systems like that of Wajo', the boundaries between gradations are blurred. The possibility of status mobility is thereby entrenched more firmly in the entire system.

So set out, the wari' system constitutes an attempt to define a single all-embracing hierarchy based on a single valent (that is, asymmetric) idiom (white blood/red blood). This opposition has been the basic principle regulating not only possible marriages, but a whole set of sumptuary laws, judicatory arrangements, restrictions on land tenure, and ways of extracting labour and payments from the populace. The scale of white blood can serve as a counter, a comprehensive measure of worth upon which various gradations of nobility could be placed. Absence of white blood demarcates the status of simple commoner. The idiom of blood thus operates very differently from those eastern Indonesian societies in which the transmission of (a homogeneously conceived) blood symbolically functions as the metaphoric channel of the 'flow of life' (Fox 1980a, 1980b) for all members. In such systems, blood is coupled with semen in order to produce the human person. The redness of blood is thus in a complementary opposition with the whiteness of semen, with the latter term sometimes transmuted into the whiteness of bone in the newly formed child, where both are necessary for the continuity of life along lines of whatever rank. ${ }^{19}$ However, the complementary duality in eastern Indonesia of red and white, 
blood and semen/bone, with both necessary for procreation, is usurped for purposes of status reckoning in the South Sulawesi context by the idiom of the dilution of white blood through marriage. White and red are differentiated within the metaphorical substance of blood itself, as the asymmetric opposition of white blood/red blood functions like the asymmetric opposition of purity/impurity in South Asia to divide the society hierarchically into ranks.

\section{Figure 7. Abstract schema of Bugis status levels}

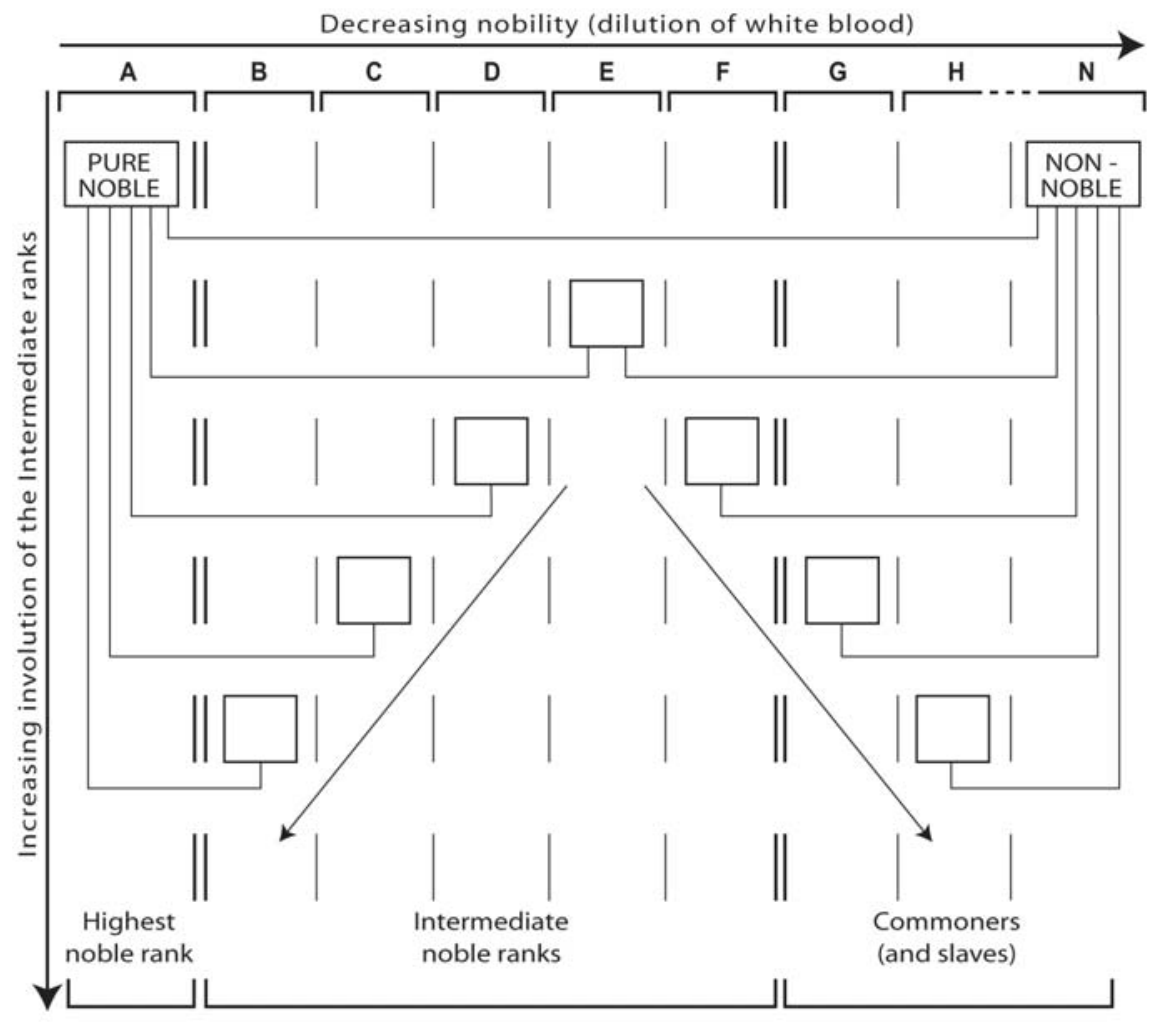


Figure 8. Schema of status levels in Wajo'

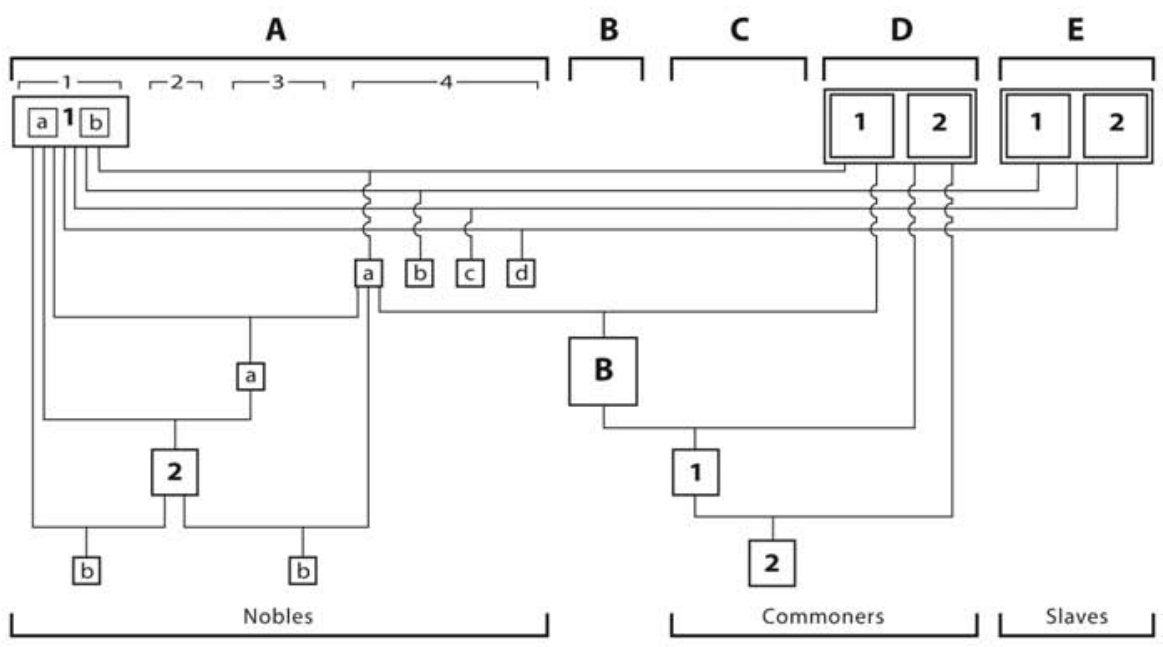

$$
\text { Key }
$$

A

A1

A1a

${ }^{\mathrm{A} 1 \mathrm{~b}}$

A2

A3

A3a

A3b

A4

A4a

A4b

A4c

A4d

B

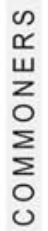

C

C1

$\mathrm{C} 2$

D

D1

D2

$\begin{array}{ll}\text { ॐ } & E \\ \text { ๘ } & D 2\end{array}$
ANA'-MATOLA (Princely nobility)

Ana'-Matola

Ana'-Matola

Ana'-Matola

Ana'-Sangaji (Princely children)

Ana'-Rajeng

Ana'-Rajeng-Lebbi

Ana'-Rajeng

Ana'-Cera'

Ana'-Céra' Sawi

Ana'-Céra' Pua

Ana'-Cera' Ampulajeng

Ana'-Céra' lyatang Dapureng

ANAKKARUNG (Children of the Rajah)

(No label given)

Tau Deceng

Tau Tongeng-Karaja

TAU MARADEKA

Tau-Maradeka-Mannennungeng

Tau-Maradeka-ri-Sampengi

ATA (Slaves)

Ata-Mana

Ata-Mabuang 
Figure 9. Schema of status levels in Mandar

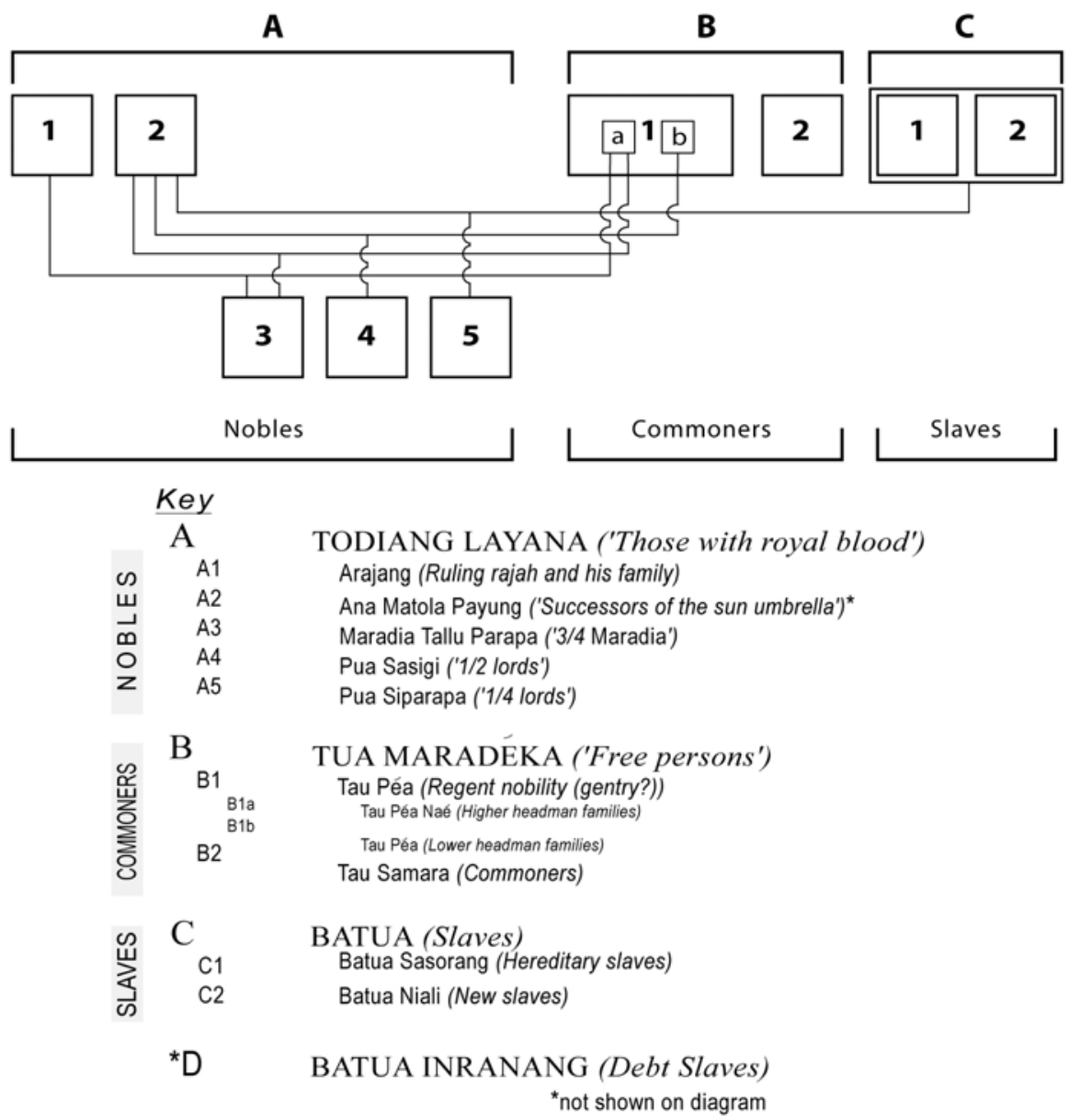


Figure 10. Schema of status levels in Goa
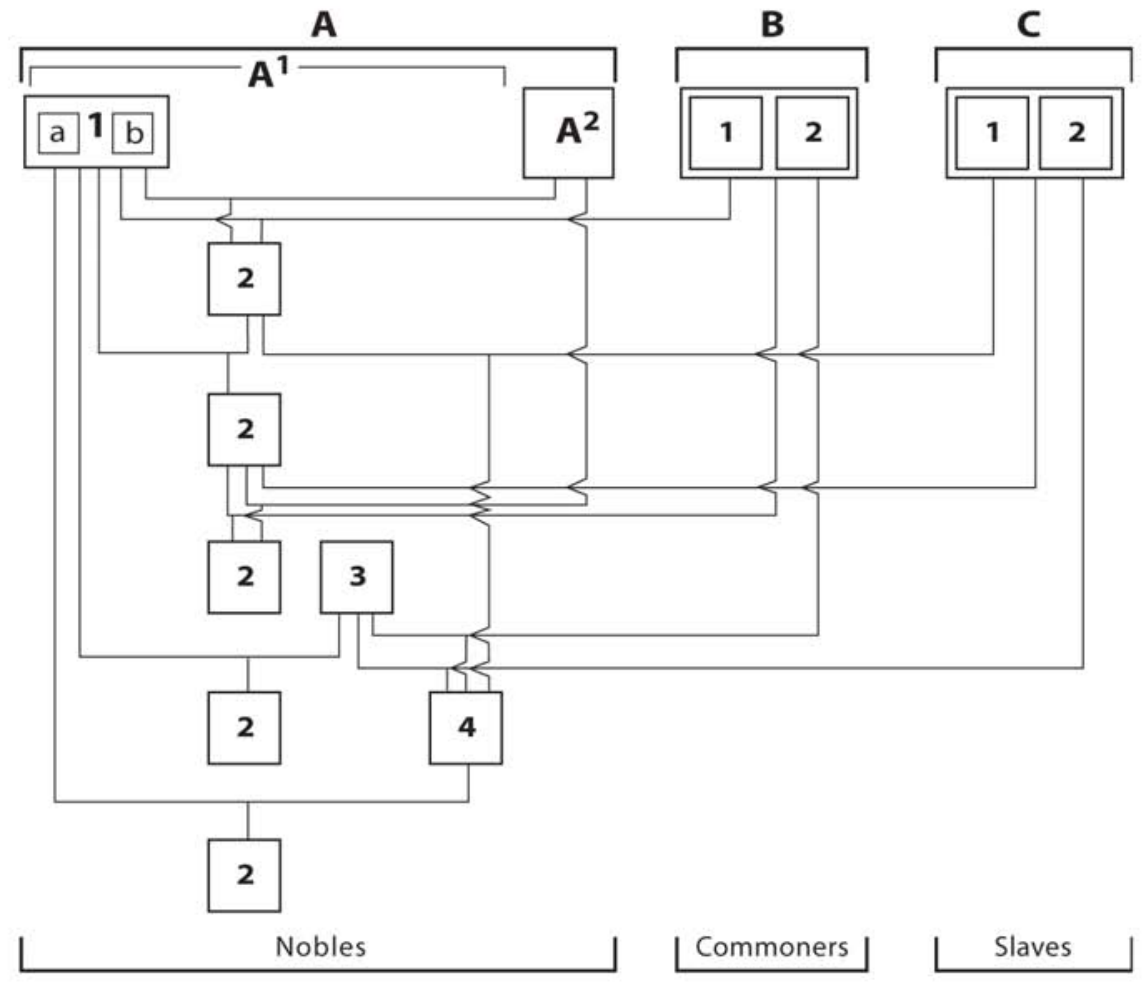

$$
\text { Key }
$$

A

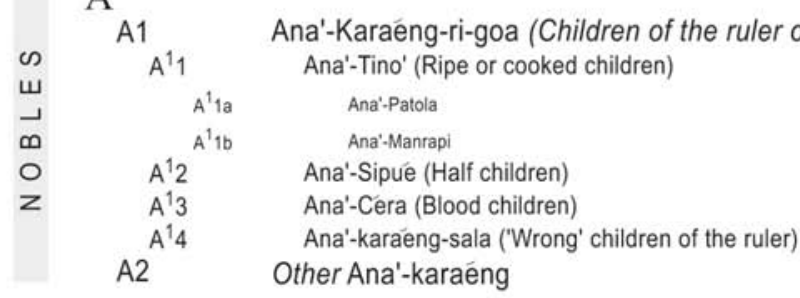

링

B TU-MARADEKA ('Free people')

B1 Tu-Baji' (Gentry)

B2 Tu-Samara (Commoners)

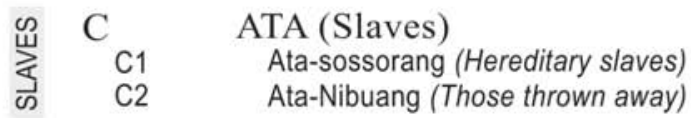


Yet, in its image of continual dilution of white blood, the wari' system also presents a dynamic that resonates with the movement from trunk to tip, with the image of 'sinking status' by which noble rulers in the Balinese negara have descended from deity to mere humanity across the generations. Even Errington herself has noted how terms for the nobility tend to implicate not only the ancestors, but also the source. In most languages of the South Sulawesi stock (Mills 1975), the usual term of reference for the highest nobles is puang, a term presumably derived from the Autronesian reflex for trunk or source, while the term of address used in Bugis realms for such high nobles, petta, is an abbreviated form of puang + ta ('our lord'). Here rather than the genealogical model of consanguines moving away from the trunk or origin line, it is a movement away from the reference line of purest white blood effected by marriage. And so it is to an examination of Bugis marriage strategies, especially among nobles possessed of white blood, that we must turn for further elucidation of the dynamics of hierarchy and precedence.

Like other societies of the archipelago, the Bugis acknowledge a distinction between younger and elder members of a particular category, as do the Makasar. For example, among siblings of the same status, the eldest is sometimes said to be expected to succeed to a parent's political office, although this expectation does not constitute a right, ${ }^{20}$ and is often overridden by considerations of personal ability and political expediency. Precisely because such considerations of strategic practice have obtruded so frequently in the choice of an actual successor, Bugis political order cannot simply be mapped out either according to either the logic of a Malay 'status lineage' (Gullick 1958), a Balinese model of 'sinking status' (Geertz 1980), a Rotinese dynastic genealogy, (Fox 1971) or a general Austronesian model of 'apical demotion' (Fox 1995), although all these notions do have their parallels in structural models that partially inform Bugis and Makasar practices of status reckoning. Younger siblings in succeeding generations do not become the branching points of groups of successively greater distance - and hence lower status - from the line of primogenitural descent from a source ancestor.

In fact, although the Bugis sibling terms kaka' and anri' (Lineton n.d.:228) encode the same differentiation of elder and younger found throughout Austronesian systems, the differential valuing of these terms reverses the tendencies found in many other systems of reckoning. Elder siblings ( $k a k a)$ are due a certain amount of respect due to their age, but it is the term for the younger sibling that has become generalized as the most common title for members of the nobility, for the noble status title $A n d i^{\prime}$ often inserted before the personal names of nobles is but a variant form of anri' (younger sibling). It is the younger or youngest sibling who is most to be cherished, deserving of the nourishing care lavished on nobles. Though not without parallel elsewhere in Indonesia (see Fox (1994:105) for a parallel valuing of the younger over the elder in the 
domain of Termanu), the younger sibling is the one accorded the value of greater honour, however ambivalently evaluated this deference is (Acciaioli 2004:74-76).

In part, this tendency may be traced to the marriage strategies of Bugis nobles. These strategies contrast overtly with those of Malay rulers and nobles. According to Gullick (1958:55ff.), a sultan in one of the indigenous Malay polities usually married a woman of royal descent as his first wife and royal consort, only subsequently taking wives of inferior status. In most cases, then, the eldest children would be born of this first wife of highest rank. Sons, especially the eldest from this union with a mother of royal descent, were known in Malay as anak gahara or waris beneh dan tanah ('heirs by the seed and soil'), while the sons from subsequent wives of lower status, who would in most cases also be younger, were known as anak gundek (children of a secondary wife). It is evident then that the Malay status lineage, with younger sons diverging from the origin line sustained by their elder siblings of royal status, derives from this precedence in the order of wives.

In contrast, high-noble leaders of Luwu', in accordance with a pattern shared elsewhere in South Sulawesi (Errington 1989:262ff.), traditionally tended to marry their wives of lower status first, ${ }^{21}$ before obtaining a wife of the same status. Thus, the marriage system, like the Malay system, included aspects of both hypergamy and endogamy, but in a temporal succession reversing the Malay order of precedence among wives. In the case of Luwu', and in other domains of South Sulawesi as well, ${ }^{22}$ marriages with wives of lower status enact a 'centrifugal' strategy aimed at producing followers of lower status (that is, diluted white blood) for the noble and his descendants of the same status. These latter children and grandchildren, offspring of a mother of the same status as their father, would continue the line of highest descent, that preserving as undiluted the purest line of white blood, a centripetal effort at conserving status. Since these latter offspring were likely to be the younger children of later noble wives, it is thus fitting that the term for younger sibling has been generalized as a status term for the nobility.

Marital strategies among Bugis and Makasar nobles in South Sulawesi, in their centrifugal and centripetal movement, present an intermeshing of precedence and hierarchy. Whereas the basic opposition of older sibling/younger sibling (kaka'/anr[d] i) echoes such distinctions of precedence as are found in the Javanese kinship terminology (Fox 1994:102-104), the appropriation of the younger sibling term for the stratum of nobles of the higher degrees of white blood operates to reinforce a pattern of ultimate marital choice that exhibits the exclusiveness characteristic of hierarchy. It is these status-endogamous marriages that have created alliances across the highest levels of nobility among the polities of South Sulawesi, so much so that the nobility has sometimes been characterized as a peninsula-wide stratum crossing all the polities. That is, the highest nobles 
across all the Bugis and Makasar domains constituted a restricted 'marriage circle', very much like that described by Pocock for subsections of high castes in India (Pocock 1957:28): 'The higher levels exclude the lower by refusing to give them their daughters in marriage and in this way preserve their distinctiveness without effecting a rupture in the caste'. In both cases, it is the women who are prohibited from marrying a husband of a lower rank, serving as the symbolic conservators of high rank (Chabot 1996). As in the case of caste itself, this process of exclusion is balanced by a process of inclusion in the South Sulawesi rank system, as noble men, especially the lower nobles who are the offspring of the lower noble and commoner wives whom their father has married first, engage in marriages with women of lower wari' rank in order to gain followers for themselves, on a smaller scale, and for their higher ranking father, on a larger scale (one might in this respect even say a more encompassing scale).

The two movements, exclusive and inclusive, or centripetal and centrifugal in Errington's terms, define the marriage system as a whole:

Thus a dual movement is required by marriage for high nobles. The one, outward and dispersing, dilutes white blood. The other, inward and conservative, preserves and perpetuates white blood. The two contradictory movements are both necessary. They are effected by the unitary high-core center when it divides itself into two aspects, one conserving, one dispersing. Another name for these two aspects is 'sister' and 'brother' (Errington 1989:260).

Of course, even a glance at the Ata Tana 'Ai system of 'father's forelock marriage' sketched above reveals that the same tendency to send brothers/sons centrifugally, and bring in daughters/sisters centripetally is operative in eastern Indonesia. The symbolic weight of the two poles is markedly similar, undermining the contrast Errington wishes to make between the salience of the brother-sister bond in the hierarchical societies of the Centrist Archipelago and of the conjugal bond in both the 'level' societies of the Centrist Archipelago and in eastern Indonesia (Errington 1989:237). But there is indeed a difference. In Luwu' and indeed perhaps most all the domains of the Bugis and Makasar in South Sulawesi, it is the exclusionary, endogamic marriage circle of the highest nobles that knits together the domains in exchanges among those of the same status. The integrity of this stratum depends upon marrying isogamically, to use Errington's term for same-status marriages (Errington 1989:259). In contrast, the anisogamic marriages do not follow a finely gradated series in which there are particular lines of marriage to be followed with specific provisioners of partners of only the next lowest level in the precedential ranking of clans or similar groups. In short, these marriages do not follow a strict line of precedence. Although there was a tendency to 'rope' local followers back into the followerships (kapolo) of high nobles by making sure that marriages were 
arranged for sons with distant cousins of lower status whose families were losing contact with the centre, these never formalized into enduring alliance structures with recognized houses of lower status along an order of precedence in Luwu' or elsewhere in South Sulawesi.

In this regard, Errington has captured a significant difference between these societies. The contrast is not nearly as stark as she would have it, but inheres in how the hierarchic aspect of the wari' system has been able to tilt the inclination of the system towards conservation of a widespread (i.e. cross-polity) centre by exclusionary endogamy and expanding of a local periphery by opportunistic marriages of ever receding kin and other followers. Imagistically, it is the difference between a profusion of casting nets with mesh of ever fluctuating extent, each linked to a common weighted centre, of purest white to be sure, for the societies of South Sulawesi on the one hand, and a series of chains forged by links of descending rank circumference, each with its origin link, all of which may themselves be linked to secure the linear chains to each other in the eastern Indonesian case on the other. The images are similar, and the construction of the meshed nets and linked chains are forged of the same metaphors of centre and periphery, trunk and tip, but the ways the mesh and links articulate with each other in their respective nets and chains do contrast.

\section{Conclusions}

As Fox (1994:88) has noted:

The concept of precedence, I would argue, is applicable to Indian society and its use is, I believe, detectable in Dumont's own analysis. Similarly, a concept of hierarchy is of great pertinence to Austronesian societies.

Perhaps it may lead to greater conceptual clarification if the term 'hierarchy' is restricted to only certain classification systems within a society, such as the varna/jati system in South Asia or the wari' system in South Sulawesi. Then, it would not be correct to assert, for example, that South Asian society is hierarchical. Rather, a system of hierarchy may be said to inform (or, more forcefully phrased, partially constitute) South Asian society, but other social mechanisms (regional affiliation, Sanskritization, jajmani labour exchanges, rural/urban contrasts, emergent class differences with capitalist penetration, and so on) inform it as well. These distinctions all operate in complex ways to reinforce or mitigate the effects of caste depending upon regional and historical vicissitudes. Similarly, precedence structures, polyvalently operating with characteristic metaphors to incorporate and differentiate constituent groups, inform Austronesian societies, but they do not exhaust the ways of assessing and asserting status in those societies, nor are they necessarily pre-eminent as a status-reckoning mechanism. In many of these societies, univalent hierarchical systems also operate to form exclusionary circles, hence also informing the 
procedures of discriminating status. Surely, it is not simply the societies of the 'Centrist Archipelago' that are structured by both hierarchy and precedence, as I am sure other East Indonesianist contributors to this volume will affirm. The analytical task then becomes one of assessing how these systems of status discrimination interact in particular contexts, and indeed reinterpret and inflect each other in ever shifting ways. If I may be forgiven the pun, the South Sulawesi case exemplifies how precedence structures may be recast(e) along hierarchical lines.

To take another case from Errington's Centrist Archipelago, perhaps (and I offer this with trepidation as a very tentative interpretation) the Balinese case demonstrates how hierarchy may be reoriented along the lines of precedence. As the example of the sinking status of the royal line of Gelgel in Bali had indicated, there was a relative ranking of Brahman and Kshatriya. Of course, these terms are part and parcel of the caste system, part of the very fabric of the Hinduism which the Balinese practise. However, as Evans, basing himself on Howe (1987), has argued:

Bali is the main bastion of Hinduism outside India and it has a caste system of sorts ... whether one decides a caste system exists or not in Bali depends on whether one is interested in religion or social stratification or some other aspect of Balinese culture. From the point of view of religious ritual ... there clearly is. But this has few ramifications in other social institutions or in inter-personal interaction as it does in India. Furthermore, the Balinese bilateral kinship system does not lend itself to endogamy and self-contained corporate groups, and caste is largely articulated through membership in caste temples. But one can decide to belong to such temples, or to belong to several of them which, as Lansing points out, 'simply translates into supporting more temple festivals and rituals and having more "kinsmen"” ([Lansing] 1983:110), or to change ones [sic] 'caste' several times in a lifetime (Evans 1993:218).

Obviously, the caste system has not retained its exclusively univalent ('encompassing' if one wishes) character in Bali. As Vickers (1989:50) notes, the priestly function is not monopolized by Brahmans in Bali, upsetting the final level of the operation of the pure/impure opposition in Dumont's model of caste. Indeed, Vickers (1989:50) argues that caste was merely an image of social order used to preserve a rank system which existed in looser fashion before the sixteenth century. The principle of sinking status allows even those of the lowest caste to claim descent across numerous generations from kings or priests of the highest castes (Vickers 1989:51).

Geertz (1980:16) has also argued that caste functions as only one title system among many and that its operation diverges from the South Asian model. In South Asia one witnesses the operation of successive differentations that 
progressively isolate the Untouchables outside the varna system, the Shudras outside the triwangsa ('twice born') category, the Vaishyas outside the dominion system, and finally the Kshatriyas outside the circle of those allowed to make sacrifices to the deities, the task left exclusively to the Brahman at the top of the purity scale. In contrast, in Bali there is a system that seems to have some of the foundations, but the Untouchables are, however, not to be found, and the Sudra are outside the Balinese variant of the triwangsa. In fact, the members of the triwangsa are referred to as wong jero ('insiders'), while the Sudra are termed wong jaba ('outsiders') (Geertz 1980:26). Here the oppositions centre/periphery and inside/outside, which structure the metaphors of precedence, are apparent in the Balinese idioms of caste hierarchy. Additionally, when considering the entitlement to power and the exercise of domination, the Brahmana largely drop away from the possibility of actual command, while the Sudra emerge as able to play a considerable role in supravillage politics. Finally,

Only the Satrias and Wesias were possessed of the one and could acquire the other so as to attain genuine authority, substantial legitimacy, and become the pivot upon which the entire system - priests, commoners, and less successful gentry — turned (Geertz 1980:27).

Geertz's use of the term 'pivot' here not only recalls the titles of Central Javanese rulers, but also suggests that the insider/outsider opposition is complemented by another opposition of the centre/periphery type, in which the Satria and Wesia realize the positively valenced term of legitimate (central) authority, while the Brahmana and Sudra occupy the negatively valenced peripheral term of debarment or 'exclusion' from such authority (Figure 11). The caste system has thus been transformed in the Balinese context into a different sort of structure, one still retaining some of the idioms of hierarchy (for example, exclusion), but also increasingly characterized by multivalent oppositions suggesting the operation of precedence.

As analysis of the cases of South Sulawesi and Bali have exemplified, and, doubtless, examination of further cases throughout the Austronesian world would also reveal (one cannot help but think of the highly articulated rank systems of Polynesia), the analytical task is not one of typifying a society as exclusively or even predominantly hierarchical or precedential, but of trying to make sense of how these modes of status discrimination interact in the everyday and ritual practices of the members of these societies. Whether precedence can be said to encompass hierarchy or hierarchy to encompass precedence is not really the issue. Neither is a priori more encompassing. I would thus disagree with the suggestion that the totality of contexts in which these different systems of precedence operate (or conflict with one another) is what may constitute hierarchy' (Fox 1994:99), for so to construe the situation is to assert hierarchy as more encompassing than precedence. Nor should precedence 
be said to encompass hierarchy precisely because in precedence there is no one privileged opposition, but rather a complex interaction of valent oppositions (Fox 1994:98). Rather, these models of status ranking are analytically distinguishable by hierarchy's emphasis on a single underlying asymmetric (that is, valent) opposition operating to construct exclusion and precedence's emphasis upon multiple valent oppositions linked to origin operating to differentiate and incorporate groups. But in actual societies these principles meet and intermesh, differentially invoked in strategies for maintaining and achieving status, setting together in unique solutions and mixtures the parameters of members' 'rivalrous delight in the "celebration of spiritual differentiation"' (Fox 1994:106).

\section{Figure 11. Balinese title system (an adaptation of Hindu caste)}




Precedence

\section{References}

Acciaioli, G.

1989 Obituary: Taroh Goh (1958-1988). Canberra Anthropology 9(1):136-138.

1990 How to win followers and influence spirits: propitiation and participation in a multi-ethnic community of Central Sulawesi, Indonesia. Anthropological Forum 6(2):207-235.

.2000 Kinship and debt: the social organization of Bugis migration and fish marketing at Lake Lindu, Central Sulawesi. Bijdragen tot de Taal-, Landen Volkenkunde 156(3):588-617.

2004 From economic actor to moral agent: knowledge, fate and hierarchy among the Bugis of Sulawesi. Indonesia 78:147-179,.

n.d. Exposing invulnerability: knowledge, competition, and hierarchy among the Bugis of South Sulawesi, Indonesia. Unpublished manuscript.

Allen, N.J.

1985 Hierarchical oppositions and some other types of relation. In R.H. Barnes, Daniel de Coppet and R.J. Parkin (eds), Contexts and levels: anthropological essays on hierarchy (JASO Occasional Papers No. 4), pp.21-32. Oxford: JASO (Journal of the Anthropological Society of Oxford).

Andaya, L.Y.

1981 The heritage of Arung Palakka: a history of South Sulawesi (Celebes) in the seventeenth century. Verhandelingen van het Koninklijk Instituut voor Taal-, Land- en Volkenkunde 91. The Hague: Martinus Nijhoff.

Babcock, T.

1991 Review of Errington, Meaning and power in a Southeast Asian realm. Pacific Affairs 64:135-136.

Blok, R.

1817[1759] History of the island of Celebes by Mr. R. Blok, governor of Maccassar. Transl. Captain J. Von Stubenvoll. (Including a Memoir by Governor Blok, Report on the Slave Trade of Maccassar by a Dutch Committee, and Trial and Sentence of Col. Filz who surrendered Fort Victory to Captain Edward Tucker) 4 vols. Calcutta: Calcutta Gazette Press.

Brooke, J.

1848 Narrative of events in Borneo and Celebes down to the occupation of Labuan (2nd edn), 2 vols. London: John Murray. 
Caldwell, I.

1991 The myth of the exemplary centre: Shelly Errington's Meaning and power in a Southeast Asian realm. Journal of Southeast Asian Studies 22(1):109-118.

Cense, A.A. with Abdoerahim

1979 Makassaars-Nederlands woordenboek met Nederlands-Makassaars register. 's-Gravenhage: Martinus Nijhoff. (Voor het Koninklijk Instituut voor Taal-, Land- en Volkenkunde.)

Chabot, H.Th.

1967 Bontoramba: a village of Goa, South Sulawesi. In Koentjaraningrat (ed.), Villages in Indonesia, pp.189-209. Ithaca, NY: Cornell University Press.

1996 Kinship, status, and gender in South Celebes. Koninklijk Instituut voor Taal-, Land- en Volkenkunde, Translation Series 25. Leiden: KITLV Press.

Dumont, L.

1980 Homo hierarchicus: the caste system and its implications. Completely revised English edition. Transl. Mark Sainsbury, Louis Dumont, and Basia Gulati. Chicago and London: The University of Chicago Press.

Errington, S.

1983a Embodied Sumange' in Luwu. Journal of Asian Studies 42(3):547-570.

1983b The place of regalia in Luwu. In L. Gesick (ed.), Centers, symbols, and hierarchies: essays on the classical states of Southeast Asia (Monograph Series No. 26), pp.194-241. Foreword by C. Geertz. New Haven: Yale University Southeast Asia Studies.

1989 Meaning and power in a Southeast Asian realm. Princeton NJ: Princeton University Press.

1990 Recasting sex, gender, and power: a theoretical and regional overview. In J.M. Atkinson and S. Errington (eds), Power and difference: gender in island Southeast Asia, pp.1-58. Stanford: Stanford University Press.

Evans, G.

1993 Hierarchy and dominance: class, status and caste. In G, Evans (ed.), Asia's cultural mosaic: an anthropological introduction, pp.205-233. New York: Prentice-Hall.

Forth, G.

1992 Conjecture, comparison and the coaxing of souls. Bijdragen tot de Taal-, Land-en Volkenkunde 148:125-128. 
Fowler, C.

1977 Ethnoecology. In D. Hardesty (ed.), Ecological Anthropology., pp. 215-243. New York: John Wiley and Sons.

Fox, J. J.

1971 A Rotinese dynastic genealogy: structure and event. In T.O. Beidelman (ed.), The translation of culture, pp.37-77. London: Tavistock.

1980a Introduction. In J.J. Fox (ed.), The flow of life: essays on eastern Indonesia, pp.1-18. Cambridge, MA: Harvard University Press.

1980b Models and metaphors: comparative research in eastern Indonesia. In J.J. Fox (ed.), The flow of life: essays on eastern Indonesia, pp.327-333. Cambridge, MA: Harvard University Press.

1989 Category and complement: binary ideologies and the organization of dualism in eastern Indonesia. In D. Maybury-Lewis and U. Almagor (eds), The attraction of opposites: thought and society in a dualistic mode, pp.33-56. Ann Arbor: University of Michigan Press.

1994 Reflections on 'hierarchy' and 'precedence'. In M. Jolly and M. Mosko (eds), Transformations of hierarchy: structure, history and horizon in the Austronesian world. History and Anthropology (Special Issue) 7:87-108.

1995 Austronesian societies and their transformations. In P. Bellwood, J.J. Fox, and D. Tryon (eds), The Austronesians: historical and comparative perspectives, pp.214-228. Canberra: Department of Anthropology, as part of the Comparative Austronesian Project, Research School of Pacific and Asian Studies, The Australian National University.

Friedericy, H.J.

1933 De standen bij de Boegineezen en Makassaren. Bijdragen tot de Taal-, Landen Volkenkunde van Nederlandsch Indië 90:447-602.

Geertz, C.

1980 Negara: the theatre state in nineteenth-century Bali. Princeton: Princeton University Press.

Goh, T.

1991 Sumba bibliography (Occasional Papers). With a foreword by James J. Fox. Canberra: Department of Anthropology, Research School of Pacific Studies, Australian National University.

1998 Communal land tenure in nineteenth century Java: the formation of Western images of the eastern village community. Canberra: Department of Anthropology, Research School of Pacific and Asian Studies, The Australian National University. 
1977 A new invitation to linguistics. Garden City: Anchor Books.

Gullick, J.M.

1958 Indigenous political systems of Western Malaya. London: Athlone Press. (London School of Economics Monographs on Social Anthropology no. 17.)

Hamonic, G.

1987 Le Langage des Dieux: Cultes et pouvoirs pré-islamiques en Pays bugis Cèlébes-Sud, Indonésie. Paris : Editions du Centre National de la Recherche Scientifique.

Harvey, B.S.

1974 Tradition, Islam, and rebellion: South Sulawesi 1950-1965. Unpublished PhD thesis, Department of Government, Cornell University.

Howe, Leo

1987 Caste in Bali and India: levels of comparison. In L. Holy (ed.), Comparative anthropology, pp.135-152. Oxford: Basil Blackwell.

Kennedy, Raymond

1953 Field notes on Indonesia: South Celebes, 1949-50, ed. H.C. Conklin. (Behavior Science Monographs.) New Haven: Human Relations Area Files.

Kooreman, P.J.

1883 De feitelijke toestand in het gouvernementsgebied van Celebes en Onderhoorigheden. De Indische Gids 5(1):167-200, 358-384, 482-498, 637-655; 5(2):135-169.

Lansing, J.S.

1983 The three worlds of Bali. New York: Praeger Publishers.

Lévi-Strauss, C.

1969 The elementary structures of kinship. Revised ed. J. H. Bell and J. R. von Sturmer, trans. R. Needham, ed. Boston: Beacon Press.

Lewis, E.D.

1988 People of the source: the social and ceremonial order of Tana Wai Brama on Flores. Verhandelingen van het Koninklijk Instituut voor Taal-, Landen Volkenkunde 135. Dordrecht: Foris.

In press The Stranger kings of Sikka. Verhandelingen van het Koninklijk Instituut voor Taal-, Land- en Volkenkunde. Leiden: KITLV Press. 
Lineton, J.A.

1975 Pasompe' Ugi': Bugis migrants and wanderers. Archipel 10:173-201. (Special issue: Célèbes-Sud.)

n.d. An Indonesian society and its universe: a study of the Bugis of South Sulawesi (Celebes) and their role within a wider social and economic system. Unpublished PhD thesis. London: School of Oriental and African Studies (SOAS), University of London.

Matthes, B.F.

1874 Boegineesch-Hollandsch woordenboek met Hollandsch-Boegineesche woordenlijst en verklaring van een tot opheldering bijgevoegden ethnographischen atlas. 's-Gravenhage: M. Nijhoff (voor het Nederlandsch Gouvernement).

1875 Bijdragen tot de ethnologie van Zuid-Celebes. 's-Gravenhage: Gebroeders Belinfante.

Mattulada

1985 Latoa: suatu lukisan analitis terhadap antropologi orang Bugis. Yogyakarta: Gadjah Mada University Press.

Millar, S.

1983 On interpreting gender in Bugis society. American Ethnologist 10(3):477-493.

1989 Bugis weddings: rituals of social location in modern Indonesia (Monograph Series, no. 29). Berkeley: Center for South and Southeast Asian Studies, University of California.

Mills, R.F.

1975 Proto South Sulawesi and proto Austronesian phonology. Unpublished PhD thesis, Linguistics, The University of Michigan.

Pelras, Ch.

1971 Hiérarchie et pouvoir traditionel en pays Wadjo' (Célèbes). Archipel pt. 1, 1:169-194; pt. 2, 2:197-223.

1996 The Bugis. Oxford: Blackwell Publishers.

Pocock, D.F.

1957 Inclusion and exclusion: a process in the caste system of Gujerat. Southwestern Journal of Anthropology 13:19-31.

Raffles, T.S.

1830 The history of Java (2nd edn), 2 vols. London: John Murray. 
Reuter, T.

1993 Precedence in Sumatra: an analysis of the construction of status in affinal relations and origin groups. Bijdragen tot de Taal-, Land-en Volkenkunde 148(3, 4):489-520.

2002 The house of our ancestors: precedence and dualism in highland Balinese society. Leiden: KITLV Press.

Sahlins, M.D.

1963 Poor man, rich man, big-man, chief: local types in Melanesia and Polynesia. Comparative Studies in Society and History 5:285-303.

Said, M.I.

1977 Kamus Bahasa Bugis-Indonesia. Jakarta: Pusat Pembinaan Dan Pengembangan Bahasa, Departemen Pendidikan Dan Kebudayaan.

Schmidt S.W., L. Guasti, C. Landé, and J.C. Scott (eds)

1977 Friends, followers, and factions: a reader in political clientelism. Berkeley: University of California Press.

Stavorinus, J.S.

1798 Voyages to the East Indies. Transl. Samuel Hull Wilcocke, 3 vols. London: G.G. and J. Robinson.

Thontowi, J.

2007 Hukum, kekerasan \& kearifan local: penyelesaian sengketa di Sulawesi Selatan. Yogyakarta: Pustaka Fahima.

Tyler, S.A.

1969 Introduction. In S.A. Tyler (ed.), Cognitive Anthropology, pp. 1-23. New York: Holt, Rinehart and Winston.

Vickers, A.

1989 Bali: a paradise created. Ringwood, Vic: Penguin Australia.

Wolters, O.W.

1982 History, culture, and region in southeast Asian perspectives. Singapore: Institute of Southeast Asian Studies.

Zerner, C. and T. Volkman

1988 The tree of desire: a Toraja ritual poem. In J.J. Fox (ed.), To speak in pairs: essays on the ritual languages of eastern Indonesia (CambridgeStudies in Oral and Literate Culture, no. 15), pp.282-305. Cambridge, Melbourne: Cambridge University Press. 


\section{ENDNOTES}

${ }^{1}$ Greenberg, more than any other linguist, has elaborated markedness relations into an entire theory of hierarchy in all levels of linguistic structure. For a brief glimpse of this achievement, see Greenberg (1977).

2 I shall return to this principle of recursiveness below in the discussions of the logic of hierarchy and of precedence. Fox (1989, this volume) has identified recursiveness as one of the underlying features of precedence as well.

3 I realize that even in this third chapter, Dumont characterizes hierarchy as 'a ladder of command in which the lower rungs are encompassed in the higher ones in regular succession' (Dumont 1980:65), but I hope to show that in his working out of his subsequent definition of hierarchy as 'the principle by which the elements of whole are ranked in relation to the whole' his notion of encompassment is not that of marking theory, but of the continued application of the same asymmetric opposition. Encompassment thus is largely synonymous with recursiveness or iteration.

4 I adopt the conventions of the English translation of the revised edition of Homo hierarchicus (Dumont 1980) in regard to the spelling and pluralization of South Asian terms. I also maintain the use of the term 'Untouchables' from this translation rather than the contemporary term of choice, Dalits.

${ }^{5}$ Reuter (2002) has already elegantly demonstrated the centrality of precedence in the analysis of the highland communities of Bali, demonstrating significant continuities with societies elsewhere in eastern Indonesia.

6 This aspect of the operation of 'sinking status' also parallels the logic of succession in the 'status lineage', as elucidated by Gullick (1958) for Malay society.

7 The only difference between the earlier concept of eastern Indonesia and the later concept of the 'Exchange Archipelago' is the inclusion of Sumatra in the latter, a point she finessed in her earlier account. Reuter (1993) has insightfully illustrated the operation of precedence structures across Sumatra. ${ }^{8}$ See also Zerner and Volkman (1988) for the bamboo clump as a model for familial relations among the Toraja, the nearest neighbours to Luwu'.

${ }^{9}$ Elder/younger terminological oppositions in eastern Indonesian societies, indeed in the terminologies of most societies in the archipelago and Austronesian world, tend not to relate only to brothers, but to siblings whose gender is not specified. Analogously, 'houses' in eastern Indonesia need not be patrilineal, as the case of the Ata Tana 'Ai testifies. In both these assumptions Errington has failed to capture the range of differences in eastern Indonesia and failed to analyse the senior/junior categorical dynamic adequately.

10 Unlike Chabot, I shall avoid the term 'class' in describing this status system, instead using such terms as 'status level' or 'rank'. Although in the past the various levels certainly corresponded more closely to classes that held differential positions with respect to the control of productive resources, this is less so in the modern context. Many commoners are members of an emergent capitalist middle class, while nobles are not infrequently impoverished. In addition, the primary means of ascribing status, the wari' system (see below), was not in the Bugis view based on such control, but conceptualized purely on the basis of marriage and descent. Having stated this, let me add that the accounts of the prerogatives of nobles in the Adatrechbundels for South Sulawesi, and especially the detailed account by Kooreman (1883) of payments due to nobles for the various types of land over which they had control, argue persuasively for identifying nobles, commoners and slaves as classes in past decades. Even in the modern context, such a rough correlation of rank with class persists in some areas. As Lineton states, 'the anakkarung [the highest rank currently recognized in Wajo, consisting of descendants of local rulers] of Anabanua are in general owners of sufficient land to be able to exist without the necessity of farming their own sawah, which is let out under sharecropping arrangements' (Lineton 1975:193). Lineton herself argues that the difference between ranks like the tau décéng and tau sama, high and ordinary commoners respectively, is ultimately based on wealth distinctions (Lineton n.d.:156). However true this may be for this particular division of commoners, it cannot account for the elaboration of distinctions among nobles given in Friedericy's analysis of wari' discussed below.

11 Letters in [] following italicized terms indicate the language of the preceding term: [B] stands for Bugis, [D] for Dutch, [I] for Indonesian.

12 The latoa genre deals with the political constitution and operation of the polity in the context of Bugis cosmology. See Mattulada (1985) for an example and analysis of this genre. Besides wari', the other elements upon which the well-being of a land depends are: 1) ade' or adat, the ancient customs; 2) undang, the laws; 3) bicara, the system of jurisprudence; and, since the advent of Islam, 4) sara' or syari'at, Islamic law. 
13 I label this phrase problematic because I disagree with Errington's characterization of sumange' as a free-floating sort of soul substance (along animatistic lines) which can be differentially concentrated and dispersed in ways that accord mainly with the social ranks of various actors. Especially, among Bugis commoners sumange' is used to indicate individual souls (along animistic lines) attached to various sorts of bodies, both animate and inanimate. Further discussion of this divergence in interpretation, ultimately grounded in whether the animatism of R.R. Marett or the animism of E.B. Tylor is more applicable in interpreting the concept of sumange', can be found in Acciaioli $(1990,2004$, n.d.).

14 Such tales thus are analogous to the pattern of 'the stranger-king' (Fox 1995:217-219, this volume; Lewis, In press). However, in the Bugis/Makasar case, there is less emphasis upon the complementary retention of an indigenous immobile authority, although the function of the bissu priests might possibly be interpreted along these lines (Hamonic 1987). There is a greater displacement of authority of all sorts into the hands of the newcomers, a usurpation that confounds the mobile/immobile distinction characteristic of the complementary conceptualization of power in societies more exclusively informed by precedence structures.

15 Numerous students of Bugis society have interpreted the tomanurung [B] tales in the I La Galigo myth cycle as symbols of the origin of larger confederacies among smaller scale Bugis communities. Kooreman explicitly advanced the theory that originally independent small realms (onafhankelijke rijkjes [D]) controlled by elders were unified into larger domains (regentschappen [D]) by the ancestors of the contemporary regents. The earlier rulers were reduced to village headmen, with only their titles and sometimes their regalia (gaukeng in Bugis; arajang in Makasar) remaining as evidence of their prior independent authority (Kooreman 1883, (1):174). Stavorinus did remark, however, upon the vestigial independence of these 'inferior chiefs, whom they call galarangs, ... [who] ... live quietly under their own laws, and in the enjoyment of their own religion ... and perform the feudal services required' (Stavorinus v.2 1798:254) by their regents and the Company (i.e. VOC).

Modern historians, particularly those teaching or trained at Cornell, have traced a more elaborate evolution of individual gaukeng communities uniting in loose confederations to mediate their inter-community quarrels and to form defensive alliances (Andaya 1981:12ff.). The rulers of the kingdoms thus formed were simply overlords, big men, or 'men of prowess' (Wolters 1982:6), viewed as concentrating in themselves greater potency (Errington 1983a). Each of the sub-rulers they dominated possessed his own localized personal following and was accorded considerable autonomy outside the range of certain specified duties.

Such a theory has obviously been considerably influenced by anthropological models of local-level leadership emerging from accounts of New Guinea and Polynesia (Sahlins 1963) and by models of patron-client relations largely developed by political scientists working in Southeast Asia, the Mediterranean and other areas (Schmidt et al. 1977). However, it remains basically an updating of the analysis of traditional political organization in South Sulawesi as fundamentally feudal. This feudal model has been invoked from at least the eighteenth century (Stavorinus 1798; Blok 1817 [written 1759]) through the nineteenth century (Raffles 1830; Brooke 1848; Kooreman 1883) and on into the twentieth century. (Friedericy 1933; Kennedy 1953; Harvey 1974) However, I refrain here from addressing the question of the extent to which this model has facilitated or distorted apprehending interpolity relations in traditional South Sulawesi. Instead, my current concern is to address the variant ways in which status is claimed and assessed among the Bugis and Makasar.

16 The white blood of the tomanurung and their descendants is compared to the white sap of the takku tree, which like the mythical heavenly figure Batara-guru and his consort from the underworld Ue Njili-timo, mediates the opposition of the upper and lower realms by growing upward from the ground to the sky in this world (Matthes 1875:4).

17 In all cases marrying downward is a possibility only acknowledged for male members of a particular rank. Marriage with a status inferior on the part of a noble woman was a heinous crime among the Bugis and Makasar (Friedericy 1933:557), resulting in the execution of the offending man (and, in most cases, the woman as well). Even among commoners, such a marriage would result at least in the exile of the couple from the local community. Friedericy states that the original ideal was status-level endogamy, but over time hypergamous marriages came to be accepted. In fact, the possibility of polygyny among the nobility required permitting such marriages. Even in the contemporay context, marriages of daughters with husbands of lower status are rejected by many parents, often leading to the scenario of elopement (silariang) and subsequent retribution carried out by the woman's brothers, father or other near relative against the offending man and often against the offending sister/daughter/niece as well (Thontowi 2007). 


\section{Precedence}

18 Lineton presents a somewhat simplified set of Bugis status levels traditionally recognized in Wajo' as a whole: 1) ana' matola, pure-blooded royalty as represented by the ruler and highest officers in the state; 2) arung, chiefs of the petty princedoms in a state; 3) tau décéng, wealthy and respected commoners who could trace an admixture of noble blood; 4) tau maradéka, free commoners; and 5) ata, slaves (Lineton 1975:191). Presumably, the same sort of specification of these status levels in terms of marriages could be made if more data were supplied concerning reckoning in the system. In fact, based on her fieldwork in the Wajo' village of Ana'banua, Lineton reports that the local commoners usually recognized only three main status divisions or tingka': 1) arung, descendants of the former Arung Ana'banua and of rulers of other wanua or villages; 2) andi', lower nobles with no direct relationship to the former ruling family, a category often not distinguished from tau décéng, the upper level of commoners; and 3) tau maradéka or tau sama, ordinary commoners (Lineton n.d.: 98).

19 Errington's phrasing of the (father's) semen/ (mother's) milk contrast may perhaps be interpreted along the lines of an asymmetric complementary opposition that serves some of the symbolic functions of the semen/blood contrast in eastern Indonesia: 'Although ToLuwu' regard themselves as related to both parents, and tend to see semen and mother's milk as parallel substances, still, semen creates, while mother's milk nourishes' (Errington 1989:261). The existence of such an opposition in Luwu' once again illustrates the permeability of the boundary between the Centrist Archipelago and the Exchange Archipelago.

20 Friedericy hesitates to label primogeniture a norm of Bugis society, though he does note its incidence in Goa (Friedericy 1933:488).

21 Modernist Islam, in the guise of Muhammadiyah and other Islamic educational and political organizations, has promulgated the limitation to four wives for all believers, thus limiting the extent to which nobles may engage in numerous marriages with commoner wives. This curbing has been heightened by Indonesian government regulations limiting civil servants to only one wife, since many nobles have now chosen political careers as a way of maintaining their power. Under these circumstances, the tendency toward status endogamy has been reinforced for those highest nobles who, if limited to only one spouse, now often prefer to seek a spouse of the same status.

22 One of my own best informants among the Bugis migrants at Lindu in Central Sulawesi was a lower noble from Boné who was a son of one of the highest Boné nobles and his first wife, who was herself of commoner status. Seeing no opportunities for himself in his Boné homeland, he chose to become a migrant (pasompe') (Acciaioli 2000:598-600; cf. Lineton 1975), unlike many of his younger siblings born to subsequently married but higher ranking wives of his father. Such an example illustrates how the Bugis fit the 'system of lateral expansion' that Fox asserts to be typical of those bilateral societies 'found on the relatively large islands of the Austronesian world, areas of potential expansion, where land and other resources are (or, in recent historical times, were once) readily available' (Fox 1995:222). In such systems relative age provides the principal axis of social differentiation, 'whereby the younger - or in a few cases, the elder - sibling simply moves away to found a new settlement' (Fox 1995:223). The latter alternative is often the case among the Bugis, in part because the first wives of Bugis nobles tended to be commoners, yielding their children as lower in rank than those of subsequent higher-status wives, as discussed in the text above. However, as has already been noted, the wari' system as a structure of status differentation in Bugis and Makasar societies also operates similarly to the 'system of apical demotion' (Fox 1995: 223), a mode of 'ever-more-exclusive' status reckoning that Fox identifies as typical of the societies on smaller islands and on the coastal margins of larger islands where trading and raiding are major preoccupations. Indeed, Fox himself identifies the societies of the former Bugis and Makassarese' as among the examples of royal societies using apical demotion as a dynastic device of the elite (Fox 1995:223). The Bugis and Makasar societies thus bridge this posited opposition of societies using lateral expansion or apical demotion, illustrating both the possible co-existence of these modes of status reckoning within the same society and the permeability of yet another analytical dichotomy, though one very different, given its loose ecological and economic underpinnings, than the Centrist and Exchange Archipelago formulated by Errington. 